\title{
Genesis and Influencing Factors of the Colour of Chrysoprase: Colourimetric Analysis Based on the Cie 1976 L*a*b* Uniform Colour Space
}

\section{Yuansheng Jiang}

China University of Geosciences (Beijing)

Ying Guo ( $\square$ guoying@cugb.edu.cn )

China University of Geosciences (Beijing)

\section{Research Article}

Keywords: chrysoprase, ultraviolet-visible and Raman spectroscopies, gemstone chromaticity

Posted Date: March 8th, 2021

DOI: https://doi.org/10.21203/rs.3.rs-267922/v1

License: (c) (i) This work is licensed under a Creative Commons Attribution 4.0 International License.

Read Full License 


\section{Genesis and influencing factors of the colour of chrysoprase: colourimetric}

\section{analysis based on the CIE $1976 L^{*} a^{*} b^{*}$ uniform colour space}

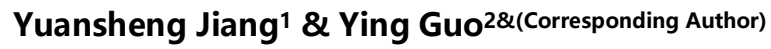

1 Department of Gemmology, China University of Geosciences (Beijing), 100083, China. E-mail: jiangyuansheng1@126.com

2 Department of Gemmology, China University of Geosciences (Beijing), 100083, China. E-mail: guoying@cugb.edu.cn

\section{Abstract}

The colour of chrysoprase is produced by $\mathrm{Ni}$ cations and influenced by other transition-metal cations and crystallinity. Presented here is a study of the origin of chrysoprase colour and an exploration of the factors that influence it from the perspective of gemstone chromaticity. Transmission electron microscopy and X-ray fluorescence, ultraviolet-visible and Raman spectroscopies are used to investigate $41 \mathrm{gem}$-quality chrysoprase samples, and the results show that chrysoprase colour results from nanometre-size inclusions of pimelite. Under a 6504-K fluorescent lamp, chrysoprase colour is divided into the grades of fancy, fancy intense and fancy deep. The lightness of chrysoprase is affected mainly by its $\mathrm{Cr}$ content, the chroma is affected by its Ni content and the hue angle is affected by the sum of its $\mathrm{Cr}$ and Fe contents. Chrysoprase hue and chroma are related significantly to the transmission window that occurs between the two main bands centred at 380 and $660 \mathrm{~nm}$ and the absorption peak at $660 \mathrm{~nm}$ in the ultraviolet-visible spectrum. Chrysoprase with low crystallinity has more $\mathrm{Ni}$ and a higher chroma.

\section{Introduction}

With a beautiful apple-green colour, chrysoprase is a fine-crystalline variety of polycrystalline quartz. It is found in quartz veins in Ni-bearing rocks all over the world, such as in Australia1, Tanzania2,3, Poland ${ }^{4}$, Kazakhstan5, South Africa and America. Although early ideas about the colour of chrysoprase included $\mathrm{Fe}$, $\mathrm{Co}$ and $\mathrm{Cu}$, it is now known to be related directly to the $\mathrm{Ni}$ content, which ranges from a few tenths of a percent to several percent by weight 6 . Chrysoprase colour arises from admixed fine-grained $\mathrm{Ni}$ compounds in the silica matrix rather than from substitutional $\mathrm{Ni}$ in the silica itself?. 
According to earlier studies on the mineralogical and colour properties of chrysoprase, the origin of its colour can be summarized into two models. In one, the colour is due to finely disseminated hydrous $\mathrm{Ni}$ silicates such as willemseite ${ }^{1}$, kerolite $^{5,8}$ and pimelite ${ }^{4}$, minerals that are usually associated with chrysoprase deposits. In the other model, the colour is due to finely divided bunsenite $(\mathrm{NiO})^{9}{ }^{10}$, the evidence for which is from cubic forms observed in transmission electron microscopy (TEM) micrographs of replicas of fractured chrysoprase and a weak reflection at $2.39 \AA$ in the X-ray pattern of chrysoprase from Kazakhstan ${ }^{10}$.

When discussing chrysoprase colour, as well as exploring its cause, one cannot neglect the influences of the transition elements, ultraviolet-visible (UV-Vis) spectrum and crystallinity of chrysoprase. The greenness of chrysoprase is in the form of a series of graded colours, which is of great value in the study of colourimetry. In recent years, colourimetry has played an important role in gemmology, involving mainly colour-change garnet ${ }^{11-14}$, tourmaline ${ }^{15,16}$, sapphire ${ }^{17}$, alexandrite $^{18}$, peridot ${ }^{19,20}$, cubic zirconia ${ }^{21}$, blue amber ${ }^{22}$, jadeite-jade $^{23-27}$, citrine $^{28}$ and amethyst ${ }^{29}$, among others. However, chrysoprase colour has been subjected to little evaluation or analysis of its influencing factors to date. Chrysoprase colour was quantified for the first time by Sachanbiński et al. based on the CIE 1931 colour-space system ${ }^{5}$, but in that system the geometrical distance between two given colours is inconsistent with human visual perception. To solve that problem, the CIE $1976 L^{\star} a^{\star} b^{\star}$ uniform colour-space system was established. As a basis for representing colours quantitatively, the CIE $1976 L^{\star} a^{\star} b^{\star}$ uniform colour space (i) has good colour uniformity, making the visual distance between colours proportional to the Euclidean distance between colour coordinates, and (ii) accords fully with the subjective law that the visual colour difference in the red-green direction is smaller than that in the yellow-blue direction 30 . The system comprises colourimetric coordinates $a^{*}$ and $b^{*}$ and lightness $L^{*}$, and the chroma $C^{*}$ and hue angle $h^{\circ}$ can be calculated from $a^{*}$ and $b^{*}$ as

$$
\begin{gathered}
C^{*}=\sqrt{a^{* 2}+b^{* 2}}, \\
h^{\circ}=\arctan \frac{b^{*}}{a^{*}} .
\end{gathered}
$$

We used 41 samples of natural chrysoprase from Australia, the colours of which displayed continuously from pale green to vivid green. To obtain the colour parameters effectively, each 
sample was cut into a polished cabochon with a diameter of $7 \mathrm{~mm}$, with no inclusion in the inner part of the sample as seen by the naked eye. Some of the samples are shown in Fig. 1.

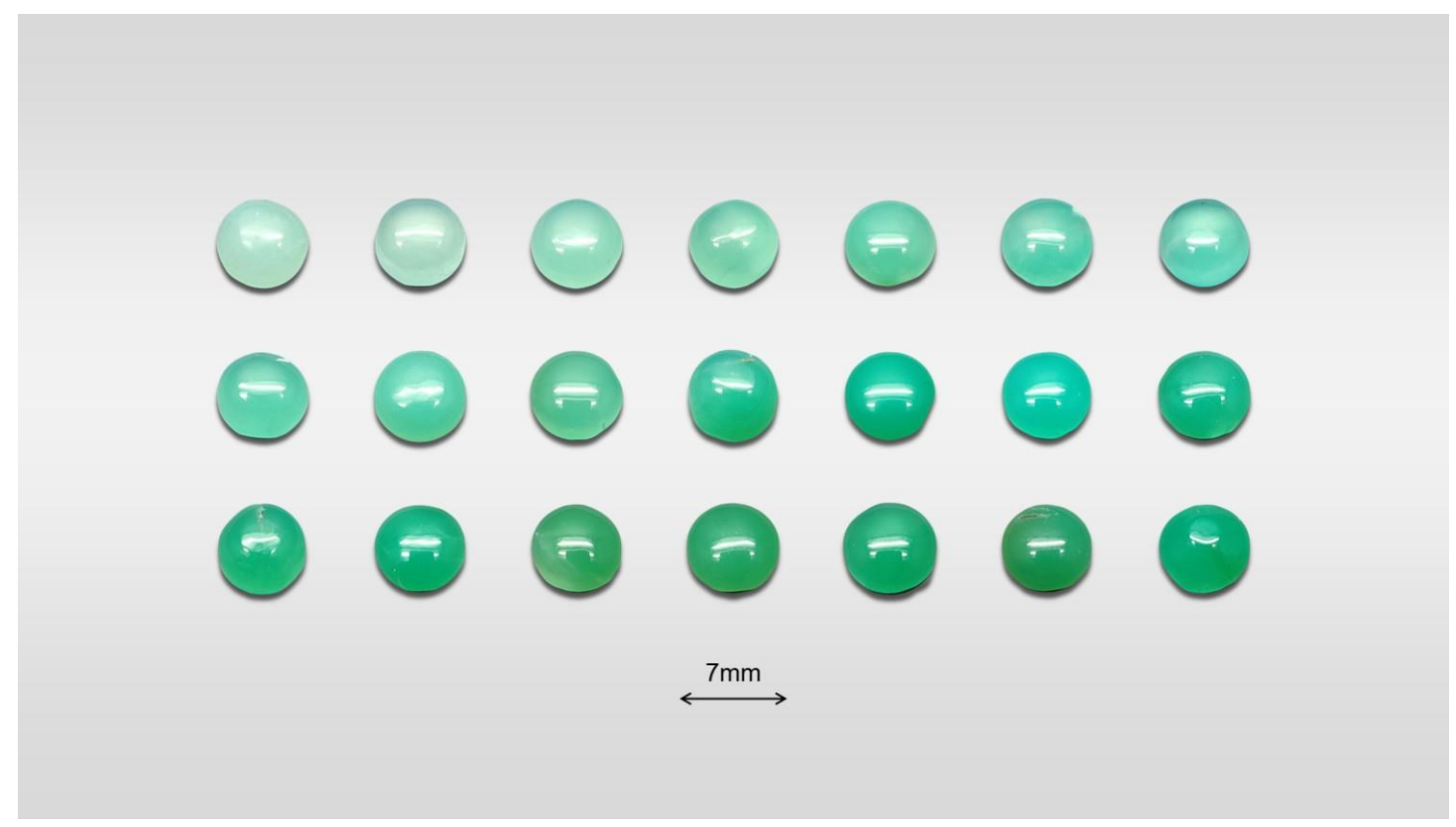

Figure 1. Photograph of some of the samples used in the present study. The round flat samples used for colour-parameter testing had an average mass of $3.96 \mathrm{~g}$, and the sample in the lower-right corner of the picture was subjected to transmission electron microscopy (TEM). 
In the present study, the cause of chrysoprase colour is analysed using TEM. Chrysoprase colour is characterized quantitatively based on the CIE $1976 L^{*} a^{*} b^{*}$ uniform colour space, and the influences of transition elements, UV-Vis spectrum and crystallinity on the colour are discussed.
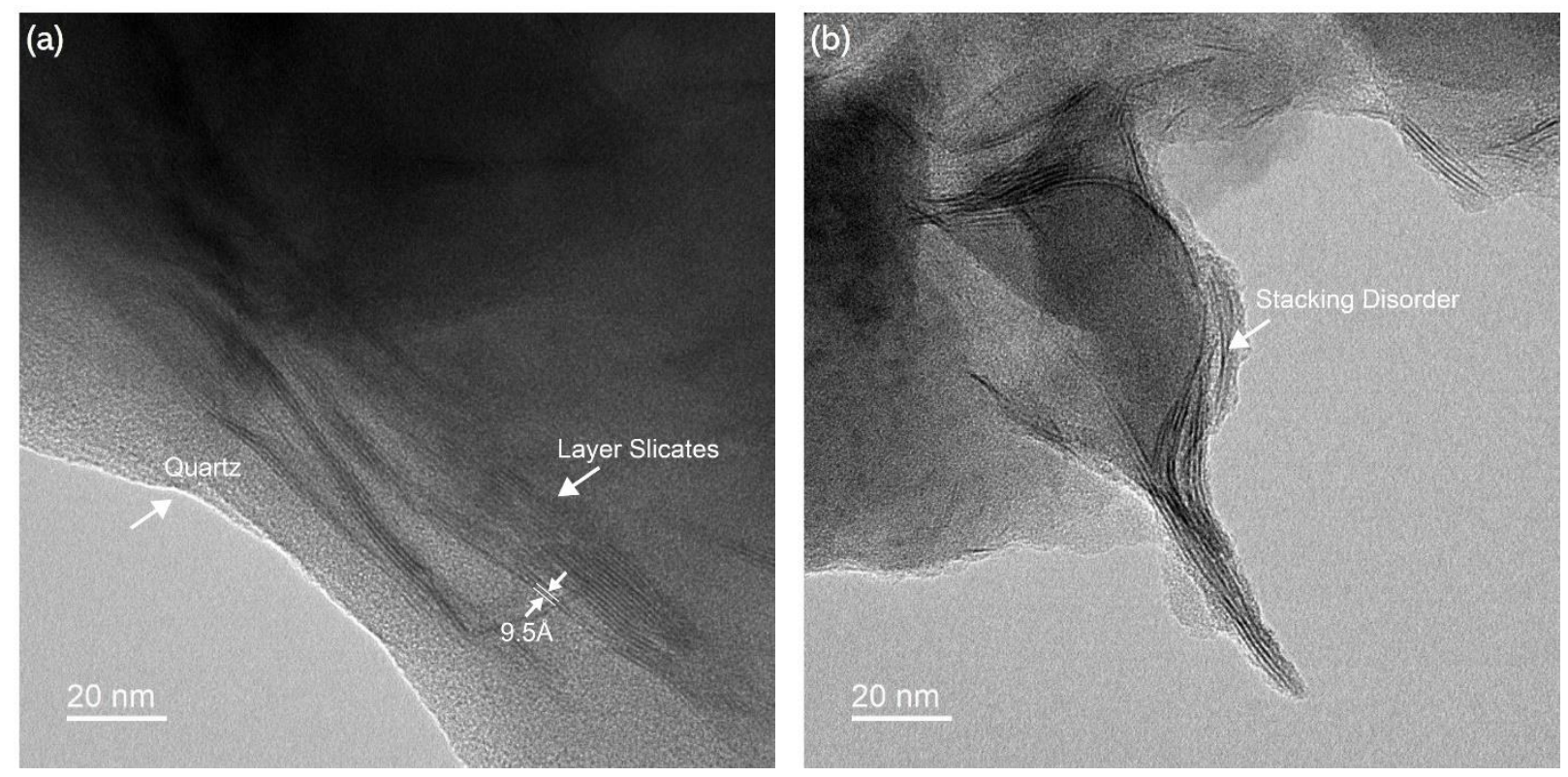

Figure 2. Results of TEM observations. (a) In chrysoprase, nanometre-size layer silicates with between five and 20 layers with similar interlayer distances of $\sim 9.5 \AA$ are found frequently in the quartz crystals and at their boundaries. (b) A TEM image of the layer silicates in chrysoprase, where the lattice fringes show the stacking disorder.

\section{Results and discussion}

\section{Transmission electron microscopy analysis}

Under TEM, layer silicates as shown in Fig. 2a are observed in the quartz crystals and at their boundaries. These layer silicates with between five and 20 layers with similar interlayer distances of $\sim 9.5 \AA$ are found frequently in chrysoprase. They commonly range in thickness from 5 to $15 \mathrm{~nm}$, but they are much longer than that and continue from one grain boundary to the next. As shown in Fig. $2 b$, their lattice fringes usually display high stacking disorder. The textures and interlayer distances indicate that the layer silicate is of the kerolite-pimelite series 31,32 , and these observations are identical to the kerolite-pimelite series observed by other investigators under TEM $5,8,33$. 
Kerolite-pimelite is solid solution series with $\mathrm{Mg}$ and $\mathrm{Ni}$ as two end-members, i.e. $\mathrm{Mg}$-rich kerolite to Ni-rich pimelite, which can be described as phases with talc affinity and extra water in their structure, within the ideal structural formula $\left(\mathrm{Mg}, \mathrm{Ni}_{3}\right)_{3} \mathrm{Si}_{4} \mathrm{O}_{10}(\mathrm{OH})_{2} \cdot \mathrm{n}\left(\mathrm{H}_{2} \mathrm{O}\right)^{34,35}$. Interference from the surrounding silica grains meant that it was impossible to obtain accurate chemical analyses of the tiny kerolite-pimelite series in the present experiment, but an energy-dispersive spectrometer was used to record some chemical-element information about the kerolite-pimelite series at the boundaries of the quartz grains as shown in Fig. 3. Si, O, Ni and Mg were selected for element detection, and a small amount of $\mathrm{Ni}$ was detected in addition to $\mathrm{Si}$ and $\mathrm{O}$, but no $\mathrm{Mg}$ was detected, indicating that the $\mathrm{Ni}$ content in this kerolite-pimelite series is higher than that of Mg, so the layer silicates observed under TEM that cause the chrysoprase colour are pimelite. 

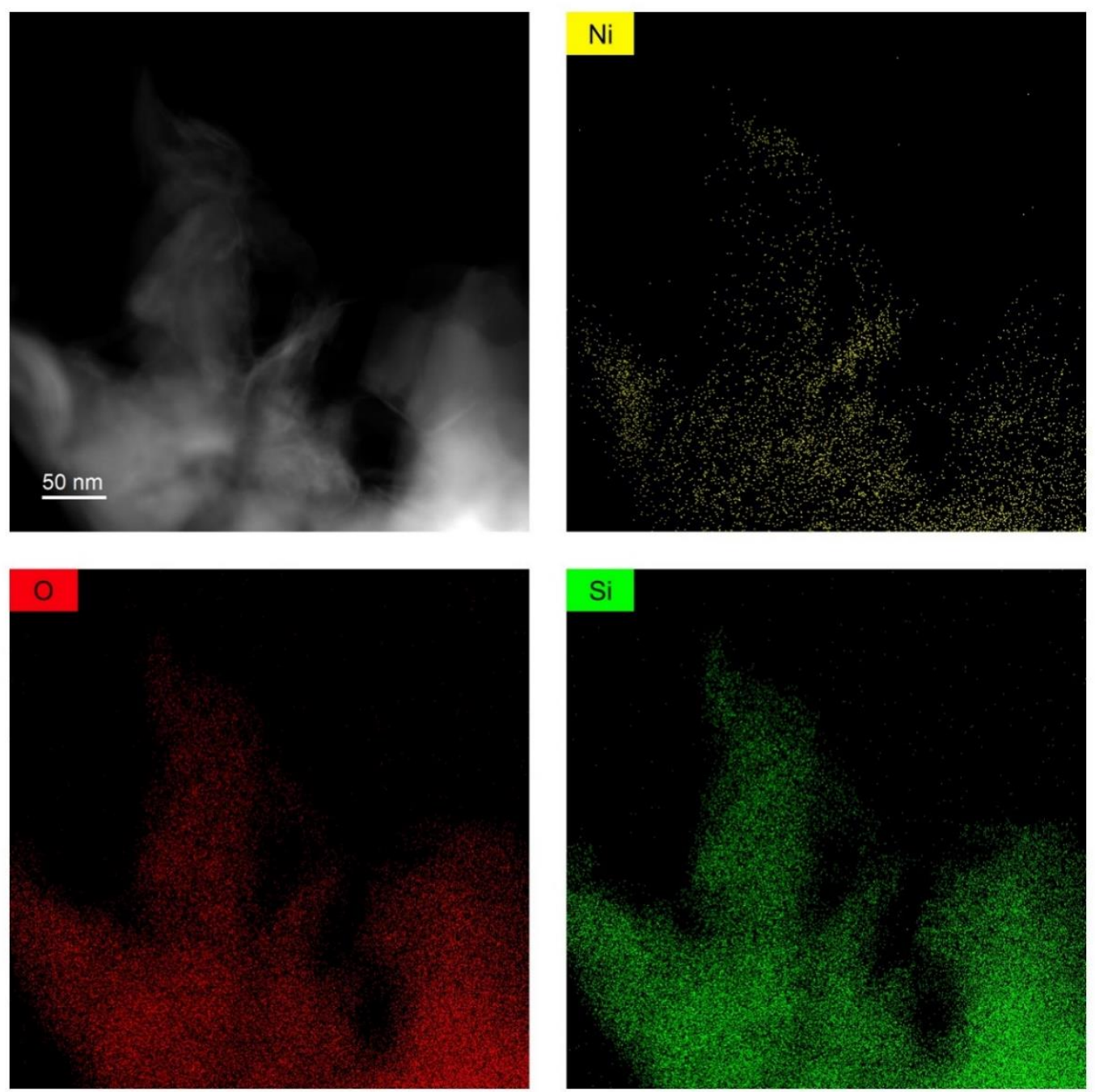

Figure 3. Elemental maps produced by energy-dispersive spectrometer. The yellow, red and green colour sites correspond to the distributions of $\mathrm{Ni}, \mathrm{O}$ and $\mathrm{Si}$, respectively. No Mg was detected.

\section{Colour quantification and classification}

Under a 6504-K fluorescent lamp, the colours of the 41 chrysoprase samples were measured to obtain their values of lightness $L^{*}(39.39-66.10)$, colourimetry indexes $a^{*}(-51.71$ to -18.81$)$ and $b^{\star}(1.87-21.29)$, chroma $C^{*}(19.05-52.82)$ and hue angle $h^{\circ}$ (147.29-174.99). These indexes are consistent with the colour appearance of chrysoprase. The colour parameters of the 41 samples are projected in the CIE $1976 L^{\star} a^{*} b^{\star}$ uniform colour space (Fig. 4), where the chroma $C^{*}$ is indicated by the distance from the projection point to the origin, and the hue angle $h^{\circ}$ is indicated 
by the angle between the line from the projection point to the origin and the $+a^{*}$ axis. The results show that the 41 chrysoprase samples were all green but in different degrees.

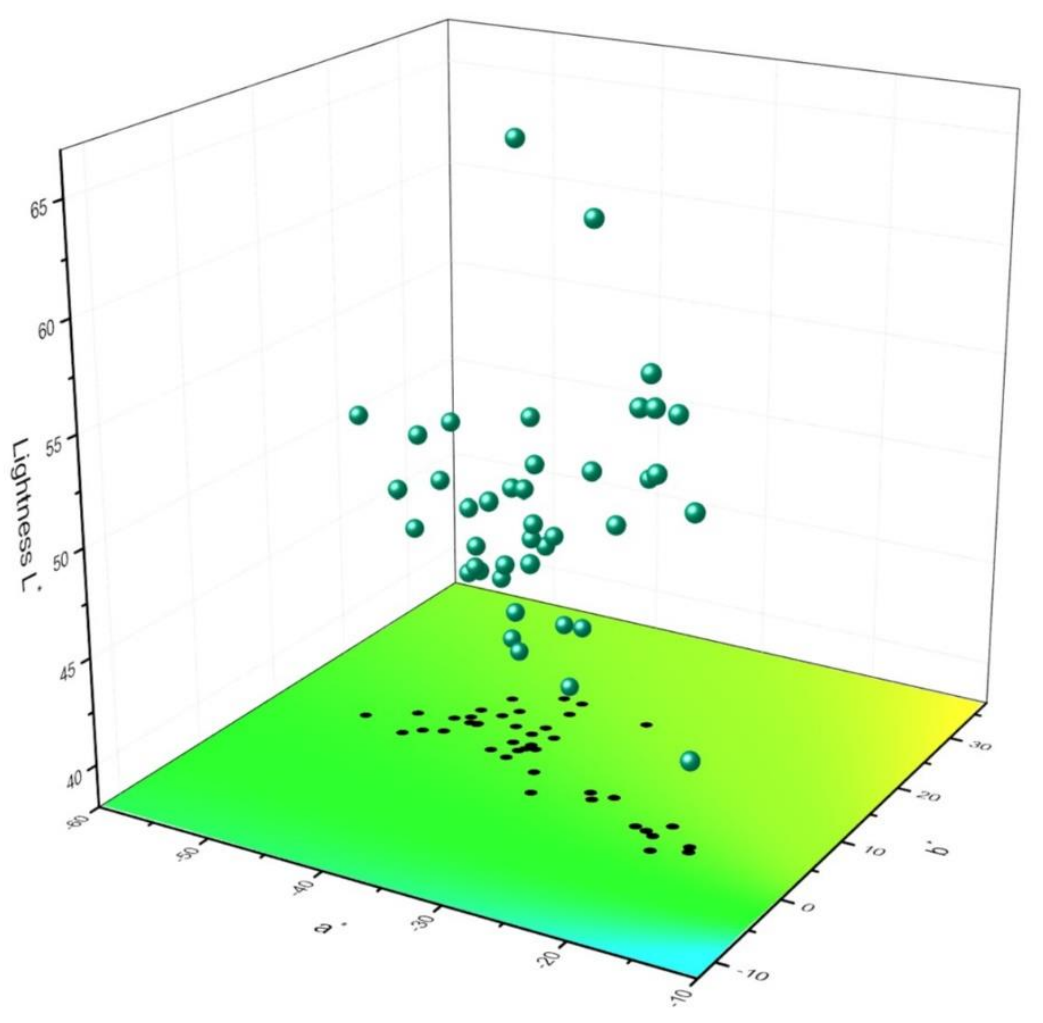

Figure 4. 41 chrysoprase green plots in CIE $1976 L^{*} a^{*} b^{*}$ uniform colour space.

Based on the CIE $1976 L^{*} a^{*} b^{*}$ uniform colour-space system, $K$-means cluster analysis and Fisher discriminant analysis were used to classify the chrysoprase colours. These two methods have been verified for classifying the colours of gemstones such as peridot ${ }^{19}$, tourmaline ${ }^{16}$, jadeite-jade ${ }^{23-27}$ and amethyst ${ }^{29}$, among others. $K$-means cluster analysis is a statistical analysis technique that divides the research object into relatively homogeneous groups. As one of the most important methods in multivariate statistical analysis, Fisher discriminant analysis summarizes the regularity of all types of samples and establishes discriminant formulae and criteria to identify the types of new sample points according to the information provided by known sample categories ${ }^{19}$.

The colour parameters $L^{*}, a^{*}$ and $b^{*}$ were analysed by $K$-means cluster analysis, and the clustering results were significant when the cluster number was 3 (Table 1). Fisher discriminant 
analysis was used to analyse these three types of chrysoprase colour, and the discriminant formulae are as follows:

$$
\begin{aligned}
& F 1=3.547 L^{*}-2.414 a^{*}+2.119 b^{*}-132.011, \\
& F 2=3.609 L^{*}-3.265 a^{*}+3.190 b^{*}-173.217, \\
& F 3=3.973 L^{*}-3.727 a^{*}+2.901 b^{*}-207.002 .
\end{aligned}
$$

\begin{tabular}{|c|c|c|c|c|c|c|}
\hline & \multicolumn{2}{|c|}{ Clustering } & \multicolumn{2}{c|}{ Error } & \multirow{2}{*}{ F } & \multirow{2}{*}{ Sig } \\
\cline { 2 - 5 } & Mean square & df & Mean square & Df & & \\
\hline $\mathrm{L}^{*}$ & 285.447 & 2 & 21.447 & 38 & 13.309 & 0.000 \\
\hline $\mathrm{a}^{*}$ & 1183.557 & 2 & 16.293 & 38 & 72.643 & 0.000 \\
\hline $\mathrm{b}^{*}$ & 364.989 & 2 & 8.390 & 38 & 43.501 & 0.000 \\
\hline
\end{tabular}

Table 1. ANOVA results for $L^{*}, a^{*}$ and $b^{*}$ of chrysoprase colour stage.

The colour parameters $L^{*}, a^{*}$ and $b^{*}$ were entered into the Fisher discriminant formulae, and Table 2 shows the accuracy of the corresponding classification results. The numbers on the diagonal indicate the prediction accuracy, while the others indicate the prediction error. Among the 41 groups of data, two are misjudged. The accuracy of color data updating is $95.12 \%$, which shows that the model is effective for classifying chrysoprase colour.

\begin{tabular}{|l|c|c|c|c|}
\hline $\begin{array}{l}\text { Fisher discriminant } \\
\text { accuracy }\end{array}$ & 1 & 2 & 3 & Total \\
\hline 1 & $\mathbf{1 0 0 \%}$ & 0.0 & 0.0 & $100 \%$ \\
\hline 2 & 0.0 & $\mathbf{9 5 . 5 \%}$ & $4.5 \%$ & $100 \%$ \\
\hline 3 & 0.0 & $12.5 \%$ & $\mathbf{8 7 . 5 \%}$ & $100 \%$ \\
\hline Classification & 1 & 2 & 3 & \\
\hline Cluster centre & 54.09 & 46.18 & 52.99 & \\
\hline$L^{*}$ & -24.54 & -39.69 & -44.94 & \\
\hline$a^{*}$ & 5.07 & 15.05 & 11.65 & \\
\hline$b^{*}$ & & & & \\
\hline Simulated colour & &
\end{tabular}

Table 2. Cluster centre and Fisher discriminant accuracy.

From the results of the $K$-means cluster analysis and Fisher discriminant analysis and by imitating the coloured-diamond grading system of the Gemological Institute of America ${ }^{36}$, the 
chrysoprase colour is divided into the grades of (i) fancy, (ii) fancy intense and (iii) fancy deep, with a hue angle ranging from $147.29^{\circ}$ to $174.99^{\circ}$ (Fig. 5a). The chrysoprase colour grading system so established is shown in Fig. $5 b$.

(a)
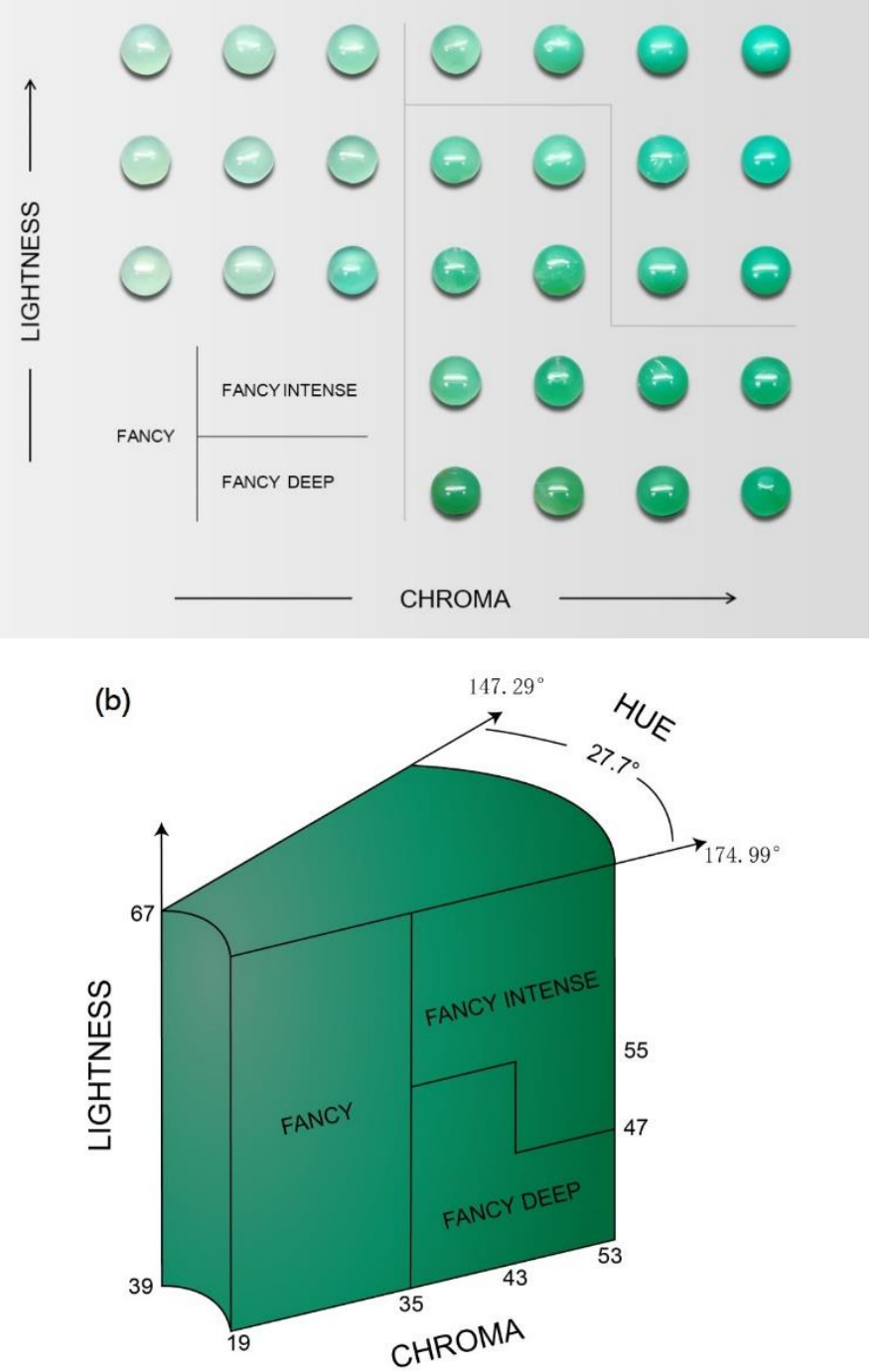

Figure 5. Colour grading of chrysoprase. (a) Chrysoprase colour is graded into the levels of fancy, fancy intense and fancy deep. (b) Chrysoprase colour grading system.

\begin{tabular}{|c|c|c|c|c|c|c|c|c|c|c|}
\hline & FD-01 & FD-02 & FI-01 & FD-03 & FI-02 & FD-04 & FI-03 & FD-05 & FI-04 & F-09 \\
\hline Samp & & & & & & & & & & \\
\hline $\mathrm{L}^{*}$ & 51.58 & 43.65 & 52.57 & 47.81 & 49.77 & 41.83 & 47.14 & 49.75 & 52.22 & 53.02 \\
\hline $\mathrm{C}^{*}$ & 38.87 & 43.01 & 52.82 & 39.48 & 48.41 & 43.39 & 50.09 & 36.07 & 47.54 & 19.47 \\
\hline
\end{tabular}




\begin{tabular}{|c|c|c|c|c|c|c|c|c|c|c|c|c|c|}
\hline $\mathrm{h}^{\circ}$ & 161.83 & 159.70 & 168.25 & 158.33 & 168.66 & 150.86 & 164.78 & 166.13 & 167.02 & 168.90 \\
\hline \multicolumn{7}{|c|}{ wt(\%)Oxides } \\
\hline $\mathrm{SiO}_{2}$ & 98.402 & 96.946 & 92.416 & 98.230 & 97.203 & 97.215 & 95.702 & 98.461 & 96.262 & 99.066 \\
\hline $\mathrm{NiO}$ & 1.192 & 2.525 & 5.631 & 1.267 & 2.345 & 2.292 & 3.752 & 1.082 & 3.250 & 0.490 \\
\hline $\mathrm{SO}_{3}$ & 0.333 & 0.426 & 0.423 & 0.424 & 0.373 & 0.373 & 0.401 & 0.390 & 0.355 & 0.336 \\
\hline $\mathrm{K}_{2} \mathrm{O}$ & 0.024 & 0.039 & 0.068 & 0.025 & 0.029 & 0.017 & 0.036 & 0.023 & 0.037 & 0.013 \\
\hline $\mathrm{Cr}_{2} \mathrm{O}_{3}$ & 0.019 & 0.027 & 0.010 & 0.017 & 0.013 & 0.009 & 0.010 & 0.013 & 0.008 & 0.010 \\
\hline $\mathrm{CaO}$ & 0.009 & 0.021 & 1.427 & 0.000 & 0.017 & 0.041 & 0.053 & 0.011 & 0.060 & 0.051 \\
\hline $\mathrm{Fe}_{2} \mathrm{O} 3$ & 0.007 & 0.002 & 0.012 & 0.007 & 0.002 & 0.033 & 0.027 & 0.008 & 0.002 & 0.014 \\
\hline $\mathrm{ZnO}$ & 0.004 & 0.007 & 0.004 & 0.003 & 0.006 & 0.002 & 0.004 & 0.003 & 0.003 & 0.002 \\
\hline $\mathrm{Others}$ & 0.010 & 0.007 & 0.009 & 0.027 & 0.012 & 0.018 & 0.015 & 0.009 & 0.023 & 0.000 \\
\hline $\mathrm{T}$ otal & 100.00 & 100.00 & 100.00 & 100.00 & 100.00 & 100.00 & 100.00 & 100.00 & 100.00 & 100.00 \\
\hline
\end{tabular}

Table 3. EDXRF data of chrysoprase samples. 


\section{Chemical composition analysis}

Energy-dispersive X-ray fluorescence (EDXRF) spectrometry is a quick and nondestructive means of detecting the presence of most elements in chrysoprase, and the test results for some of the samples are given in Table 3. The results show that the range of weight percentage [wt\%] of the main oxide in the 41 chrysoprase samples is $\mathrm{w}\left(\mathrm{SiO}_{2}\right)=92.416-99.099$, and those of the other oxides are $\mathrm{w}(\mathrm{NiO})=0.380-5.631, \mathrm{w}\left(\mathrm{SO}_{3}\right)=0.217-0.470, \mathrm{w}\left(\mathrm{K}_{2} \mathrm{O}\right)=0-0.077, \mathrm{w}\left(\mathrm{Cr}_{2} \mathrm{O}_{3}\right)=0.008-$ $0.035, \mathrm{w}(\mathrm{CaO})=0-1.427, \mathrm{w}\left(\mathrm{Fe}_{2} \mathrm{O}_{3}\right)=0-0.025$ and $\mathrm{w}(\mathrm{ZnO})=0-0.018$. Of these, $\mathrm{Ni}, \mathrm{Cr}$ and $\mathrm{Fe}$ are transition-metal elements, which are often related to the colour of gemstones. Bivariate correlation analysis was used to analyse the correlation between the contents of transition-metal elements and the colour parameters of the 41 chrysoprase samples (Table 4). The test was twotailed, and the linear relationship between the two groups of data can be judged by the Pearson correlation coefficient $r$ : when $|r|<0.3$, there is weak or no correlation; when $0.3 \leq|r|<0.5$, there is low correlation; when $0.5 \leq|r|<0.8$, there is moderate correlation; when $|r| \geq 0.8$, there is high correlation.

\begin{tabular}{|c|c|c|c|c|}
\hline Oxide & & $\mathrm{L}^{*}$ & $\mathrm{C}^{*}$ & $\mathrm{~h}^{\circ}$ \\
\hline \multirow{2}{*}{$\mathrm{NiO}$} & $\mathrm{r}$ & $-0.479^{* *}$ & $0.832^{* *}$ & -0.308 \\
\cline { 2 - 5 } & $\mathrm{Sig}$ & 0.002 & 0.000 & 0.050 \\
\hline \multirow{2}{*}{$\mathrm{Cr}_{2} \mathrm{O}_{3}$} & $\mathrm{r}$ & $-0.685^{* *}$ & $0.502^{* *}$ & $-0.695^{* *}$ \\
\cline { 2 - 5 } & $\mathrm{Sig}$ & 0.000 & 0.001 & 0.000 \\
\hline \multirow{2}{*}{$\mathrm{Fe}_{2} \mathrm{O}_{3}$} & $\mathrm{r}$ & 0.022 & -0.111 & -0.167 \\
\cline { 2 - 5 } & $\mathrm{Sig}$ & 0.890 & 0.491 & 0.297 \\
\hline \multirow{2}{*}{$\mathrm{Cr}_{2} \mathrm{O}_{3}+\mathrm{Fe}_{2} \mathrm{O}_{3}$} & $\mathrm{r}$ & $-0.587^{* *}$ & $0.377^{*}$ & $-0.704^{* *}$ \\
\cline { 2 - 5 } & $\mathrm{Sig}$ & 0.000 & 0.015 & 0.000 \\
\hline
\end{tabular}

Table 4. Results of bivariate correlation analysis. ** at level 0.01 (double tail), the correlation was significant. * at level 0.05 (double tail), the correlation was significant.

The results show high positive correlation between $\mathrm{w}(\mathrm{NiO})$ and chroma $C^{*}$ in chrysoprase $\left(r_{C^{*}}=0.832\right)$, as shown in Fig. 6a, and low negative correlations with lightness $L^{*}$ and hue angle $h^{\circ}$ $\left(r_{L^{\star}}=-0.479, r_{h^{\circ}}=-0.308\right)$. There were moderate negative correlations between $\mathrm{w}\left(\mathrm{Cr}_{2} \mathrm{O}_{3}\right)$ and lightness $L^{*}$ and hue angle $h^{\circ}\left(r_{L^{*}}=-0.685, r_{h^{\circ}}=-0.695\right)$, as shown in Fig. $6 \mathrm{~b}$, and moderate 
positive correlation $\left(r_{C^{*}}=0.502\right)$ with chroma $C^{*}$. Sachanbiński et al. ${ }^{5}$ reasoned that the yellow hue of chrysoprase is due to the existence of $\mathrm{Fe}^{3+}$. Although the present bivariate correlation analysis shows no significant correlation between $\mathrm{w}\left(\mathrm{Fe}_{2} \mathrm{O}_{3}\right)$ and the colour parameters, the sum of $\mathrm{w}\left(\mathrm{Fe}_{2} \mathrm{O}_{3}\right)$ and $\mathrm{w}\left(\mathrm{Cr}_{2} \mathrm{O}_{3}\right)$ has significant negative correlation with the hue angle $h^{\circ}$; the Pearson correlation coefficient $r$ is -0.704 , whose absolute value is greater than that of the Pearson correlation coefficient of $\mathrm{w}\left(\mathrm{Cr}_{2} \mathrm{O}_{3}\right)$ and $h^{\circ}$. Therefore, the hue angle of chrysoprase is affected by the content of $\mathrm{Fe}$ and $\mathrm{Cr}$; i.e. the higher the sum of the $\mathrm{Fe}$ and $\mathrm{Cr}$ contents, the lower the hue angle, and the hue tends to yellowish green (Fig. 6c).
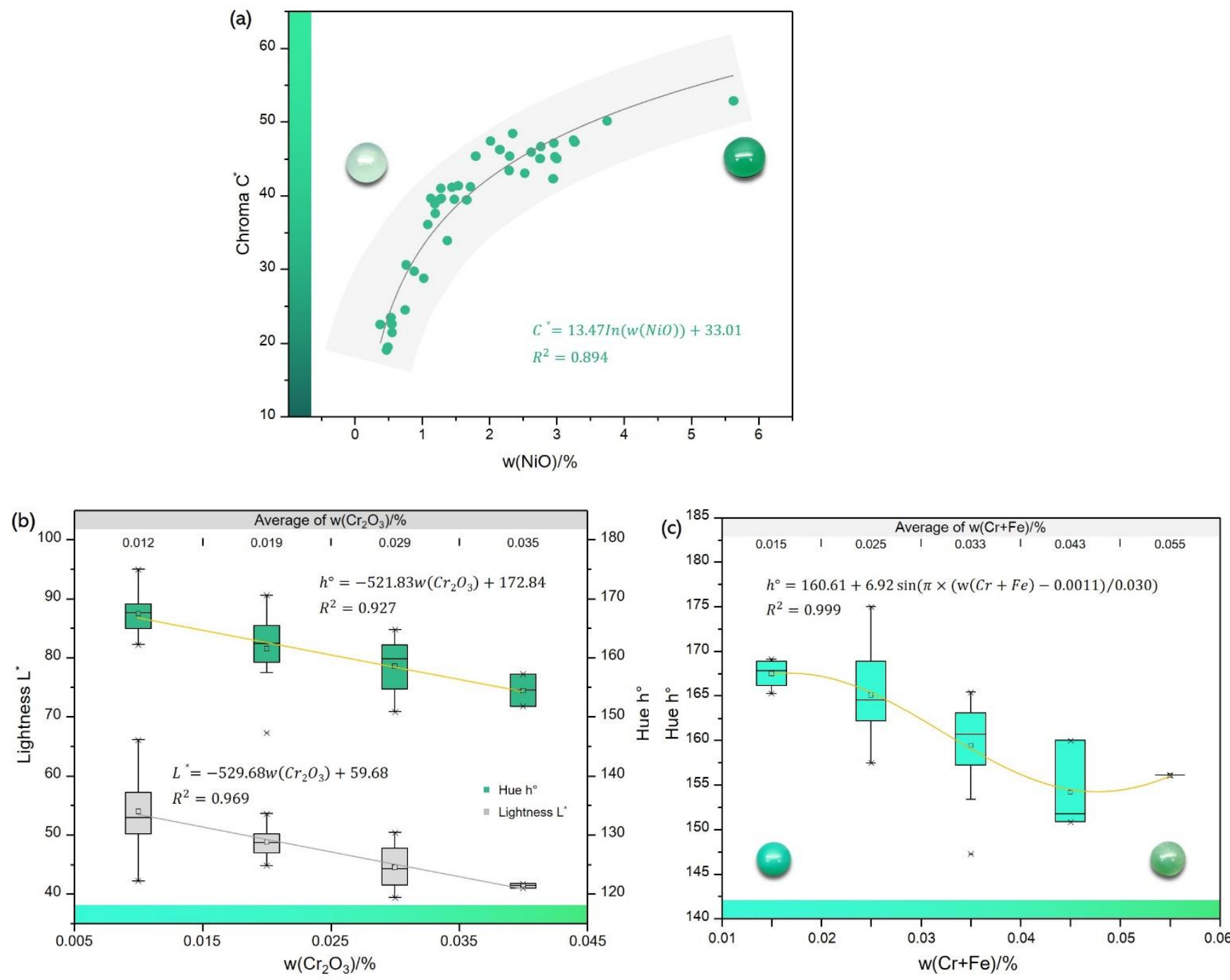

Figure 6. Relationship between colour parameters and transition-metal elements. (a) There

is a highly positive correlation between $\mathrm{Ni}$ content and chroma. (b) With increasing $\mathrm{Cr}$ content, the lightness and hue angle exhibit downward trends. (c) Both $\mathrm{Cr}$ and Fe affect the hue angle; the higher the content of $\mathrm{Cr}$ and $\mathrm{Fe}$, the smaller the hue angle. 

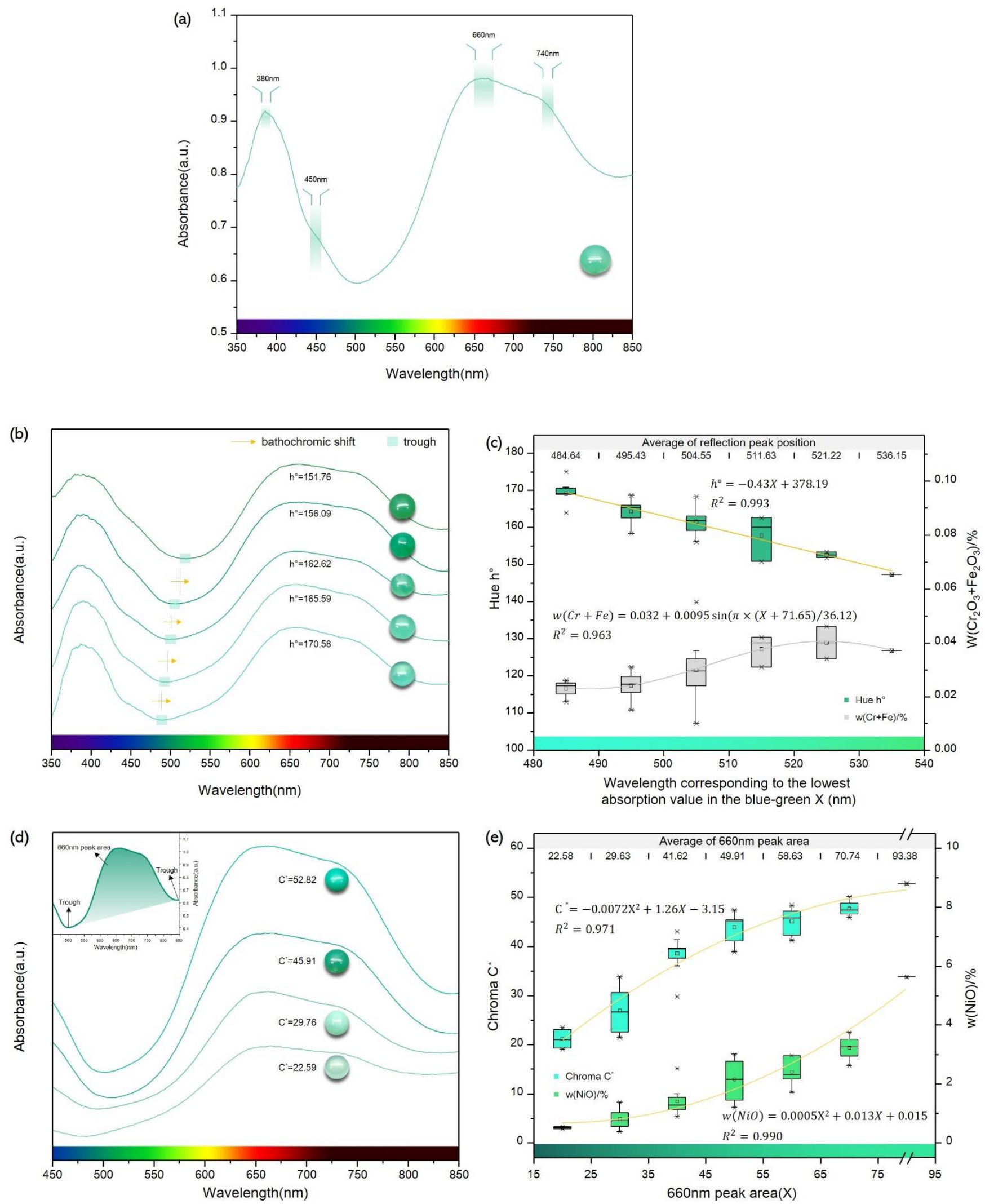

Figure 7. UV-Vis spectra for chrysoprase samples. (a) The UV-Vis spectra of chrysoprase are characterized by $\mathrm{Ni}^{2+}$ absorption features. (b) The transmission 
window between the two main bands of chrysoprase centred at 380 and $660 \mathrm{~nm}$ is responsible for the hue of the samples. (c) Relationship between the wavelength corresponding to the lowest absorption value in the blue-green region and hue and $\mathrm{w}\left(\mathrm{Cr}_{2} \mathrm{O}_{3}+\mathrm{Fe}_{2} \mathrm{O}_{3}\right)$. (d) The larger the area of the $660-\mathrm{nm}$ absorption peak, the greater the chroma of chrysoprase. (e) Relationship between the 660-nm peak area and chroma and $\mathrm{w}(\mathrm{NiO}) \%$. The chroma and $\mathrm{Ni}$ content of chrysoprase increase with increase of the $660-\mathrm{nm}$ peak area.

\section{UV-Vis spectral analysis}

The UV-Vis spectra of chrysoprase are shown in Fig. 7a, and the individual absorptions are listed and assigned in Table 5. All the spectra are consistent with the presence of octahedrally coordinated $\mathrm{Ni}^{2+}$ ions and agree with the spectra of other $\mathrm{Ni}^{2+}$-containing minerals in the literature2,37-39. The bands near 380 and $660 \mathrm{~nm}$ correspond to spin-allowed d-d transitions, and the shoulders near 450 and $740 \mathrm{~nm}$ correspond to spin-forbidden $d-d$ transitions ${ }^{31,39}$.

\begin{tabular}{|c|c|}
\hline Wavelength $(\mathrm{nm})$ & Assignment \\
\hline 380 & ${ }^{3} \mathrm{~A}_{2 \mathrm{~g}}(\mathrm{~F}) \rightarrow{ }^{3} \mathrm{~T}_{1 \mathrm{~g}}(\mathrm{P})$ \\
\hline 450 & ${ }^{3} \mathrm{~A}_{2 \mathrm{~g}}(\mathrm{~F}) \rightarrow{ }^{1} \mathrm{~T}_{2 \mathrm{~g}}(\mathrm{D})$ \\
\hline 660 & ${ }^{3} \mathrm{~A}_{2 \mathrm{~g}}(\mathrm{~F}) \rightarrow{ }^{3} \mathrm{~T}_{1 \mathrm{~g}}(\mathrm{~F})$ \\
\hline 740 & ${ }^{3} \mathrm{~A}_{2 \mathrm{~g}}(\mathrm{~F}) \rightarrow{ }^{1} \mathrm{E}_{\mathrm{g}}(\mathrm{D})$ \\
\hline
\end{tabular}

Table 5. Visible absorptions and assignments for chrysoprase.

The transmission window that occurs between the two main bands of chrysoprase centred at 380 and $660 \mathrm{~nm}$ is responsible for the hue of the samples (Fig. 7b). Upon changing the wavelength corresponding to the lowest absorption value in the blue-green region of the spectrum, the hue angle of chrysoprase also changes. When the wavelength decreases, the hue angle increases and the hue shifts to bluish green; when the wavelength increases, the hue angle decreases and the hue shifts to yellowish green. 
The presence of $\mathrm{Cr}^{3+}$ and $\mathrm{Fe}^{3+}$ in chrysoprase results in its yellowish hue, this being because the absorptions related to the spin-allowed $d$-d transitions ${ }^{4} \mathrm{~A}_{2 g}(F) \rightarrow{ }^{4} \mathrm{~T}_{1 \mathrm{~g}}(\mathrm{~F}),{ }^{4} \mathrm{~T}_{19}(\mathrm{P})$ caused by $\mathrm{Cr}^{3+}$ and the charge transfer $\mathrm{O}^{2-} \rightarrow \mathrm{Fe}^{3+}$ overlap in the short-wave part of the spectrum. Consequently, the wavelength corresponding to the lowest absorption value in the blue-green region of the spectrum shifts to the short-wave direction with increasing sum of $\mathrm{Cr}$ and $\mathrm{Fe}$ contents. As shown by Fig. $7 c$, the colour change exhibits decreasing hue angle, and the hue tends to yellowish green, which is coincident with the former conclusion that the sum of $\mathrm{Cr}$ and $\mathrm{Fe}$ contents is related negatively to the hue angle.

Sachanbiński et al. ${ }^{5}$ reasoned that $\lambda$-dependent light scattering on microdefects in the chalcedony matrix (e.g. silica globules, nano- and micrometre-size mineral inclusions and gasliquid inclusions) would lead to a decrease in the absorption within the short-wave part of the spectrum, so that the wavelength corresponding to the lowest absorption value in the blue-green region of the spectrum shifted to the short-wave direction. The colour change was characterized by increasing hue angle, and the hue tended to bluish green.

There is a highly positive correlation between the area of the $660-\mathrm{nm}$ absorption peak and the colour of chrysoprase, and the Pearson correlation coefficient $r$ is 0.889 . Fig. $7 \mathrm{~d}$ shows directly that the larger the area of 660-nm absorption peak, the greater the chroma of chrysoprase. The absorption at $660 \mathrm{~nm}$ is caused by the $\mathrm{d}-\mathrm{d}$ electron transition of $\mathrm{Ni}^{2+}$. As shown in Fig. 7e, increasing $\mathrm{Ni}$ content leads to increased area of the absorption peak at $660 \mathrm{~nm}$, so the chrysoprase colour will also change, as shown by the increasing chroma. This is consistent with the conclusion that there is high positive correlation between $\mathrm{w}(\mathrm{NiO})$ and the chroma $\mathrm{C}^{*}$ of chrysoprase as obtained by EDXRF analysis. 

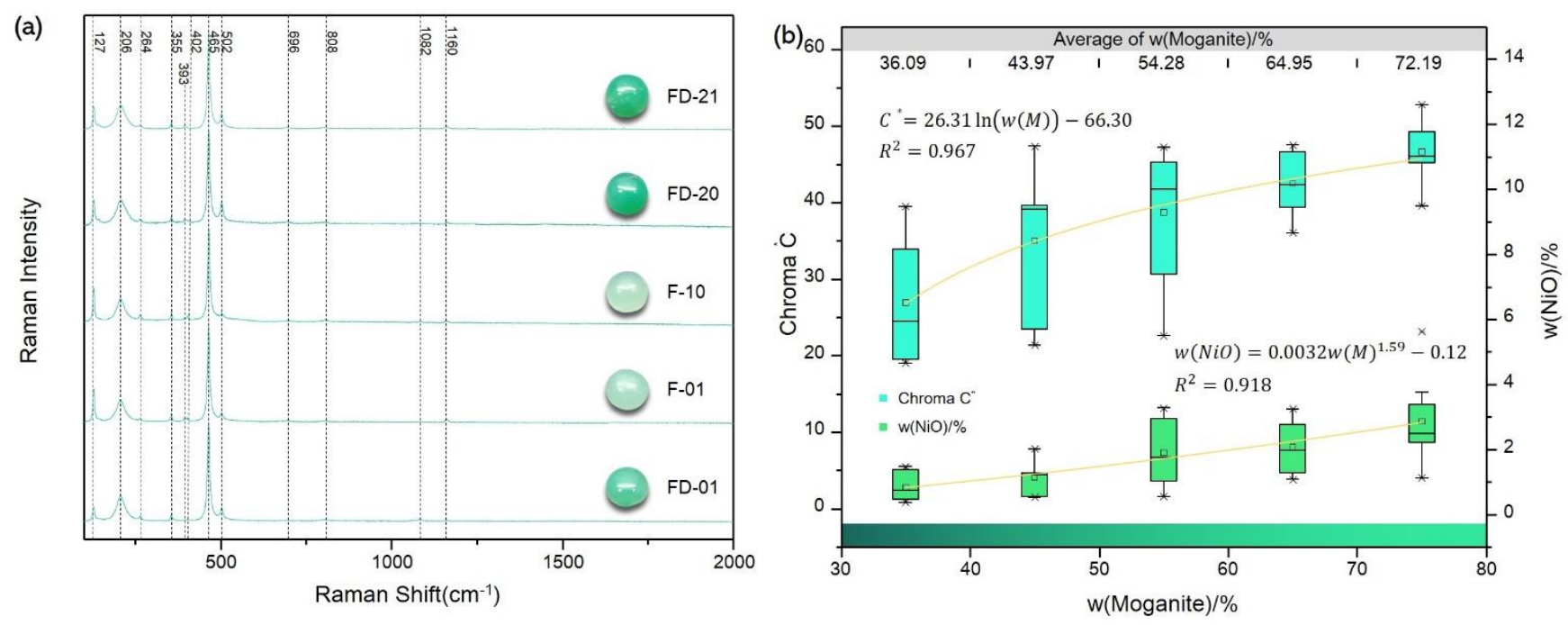

Figure 8. (a) Raman spectra of chrysoprase. All samples show standard Raman peaks of $\alpha$-quartz and the characteristic peak of moganite of $502 \mathrm{~cm}^{-1}$. (b) Relationship between $w($ Moganite) and chroma and $w(\mathrm{NiO})$. The chroma and Ni content of chrysoprase both increase with increasing moganite content. 


\section{Crystallinity analysis}

Crystallinity can refer to the relative ratio of amorphous body to crystal in a substance, as well as the degree of regular arrangement of internal particles and the number of structural defects ${ }^{40}$. The crystallinity referred to herein is the latter type. Gawel et al. ${ }^{6}$ reasoned that if the crystallinity of silica is lower, then there will be more microstructure defects, which can hold more $\mathrm{Ni}$-containing compounds and affect the colour of chrysoprase. In the present study, to analyse how chrysoprase crystallinity affects colour, the crystallinity of the chrysoprase samples is described semi-quantitatively by means of non-destructive Raman spectroscopy.

The Raman spectra of the chrysoprase samples are shown in Fig. 8a, and all the samples show standard Raman peaks of $\alpha$-quartz ${ }^{41}$, which are listed in Table 6. As well as $\alpha$-quartz, most of the samples have the characteristic $502-\mathrm{cm}^{-1}$ peak of moganite, which is related mainly to the symmetrical stretching bending vibration of $\mathrm{Si}-\mathrm{O}-\mathrm{Si}$ in the tetrahedral ring of silica tetrahedron ${ }^{41}$. As a homomorphic variant of quartz, moganite is often symbiotic with polycrystalline quartz, and according to previous studies, its relative content is related negatively to the crystallinity of polycrystalline quartz ${ }^{40,42}$, which can be explained from the perspective of crystal structure. The crystal structure of moganite has been described as monoclinic with alternate stacking of layers of (1011) slices of left- and right-handed $\alpha$-quartz corresponding to a periodic Brazil-law twinning on the unit-cell scale ${ }^{43}$. However, most of the quartz without double crystals in nature is composed of left- or right-handed $\alpha$-quartz. It is inferred that the appearance of moganite microcrystals in $\alpha$-quartz can be regarded as a structural defect, which causes the crystallinity of polycrystalline quartz mainly composed of $\alpha$-quartz reduced 40 .

\begin{tabular}{|c|c|}
\hline$v\left(\mathrm{~cm}^{-1}\right)$ & Mode Symmetry \\
\hline 127 & $\mathrm{E}_{(\mathrm{LO}+\mathrm{TO})}$ \\
\hline 206 & $\mathrm{~A}_{1}$ \\
\hline 264 & $\mathrm{E}_{(\mathrm{LO}+\mathrm{TO})}$ \\
\hline 355 & $\mathrm{~A}_{1}$ \\
\hline 393 & $\mathrm{E}_{(\mathrm{TO})}$ \\
\hline 402 & $\mathrm{E}_{(\mathrm{LO})}$ \\
\hline 464 & $\mathrm{~A}_{1}$ \\
\hline 696 & $\mathrm{E}_{(\mathrm{LO}+\mathrm{TO})}$ \\
\hline
\end{tabular}




\begin{tabular}{|c|c|}
\hline 808 & $\mathrm{E}_{(\mathrm{LO})}$ \\
\hline 1082 & $\mathrm{~A}_{1}$ \\
\hline 1160 & $\mathrm{E}_{(\mathrm{LO}+\mathrm{TO})}$ \\
\hline
\end{tabular}

Table 6. Raman frequencies of $\alpha$-quartz.

Götze et al. ${ }^{44}$ established a model for calculating the content of moganite in a sample using $\alpha$-quartz as the internal standard. The Raman peaks of different ratios of $\alpha$-quartz and moganite were measured under different conditions, and the Raman band integral ratio of moganite at $502 \mathrm{~cm}^{-1}$ and $\alpha$-quartz at $465 \mathrm{~cm}^{-1}$ were calculated. After description and calibration, the function fitting curve of moganite content and Raman band integral ratio $I_{(502)} / I_{(465)}$ is obtained, so the moganite content of the samples can be calculated by substituting the Raman band integral ratio $I_{(502)} / I_{(465)}$ into the curve. Herein, the Raman peaks located at 502 and $465 \mathrm{~cm}^{-1}$ are fitted by a Gaussian Lorentzian function using the LabSpec software (version 6; Horiba Ltd., Japan), and as a result the integral ratio of the Raman band is obtained. The calculation results are substituted into the function fitting curve of moganite content and Raman band integral ratio $I_{(502)} / I_{(465)}$ to calculate the moganite content of the samples. The content of moganite is correlated negatively with the crystallinity of polycrystalline quartz, thus the relative degree of the crystallinity of the samples is known.

The moganite content of the 41 chrysoprase samples used in this experiment varies from 20 to $80 \mathrm{wt} \%$. According to the difference of moganite content, the 41 chrysoprase samples are divided into six groups (Table 7). As shown in Fig. 8b, the chroma and Ni content of chrysoprase both increase with increasing moganite content. The higher the content of moganite, the lower the crystallinity of silica, and the lower the crystallinity of silica, the more microstructure defects in the samples, which can accommodate more $\mathrm{Ni}$-rich pimelite. Increasing $\mathrm{Ni}$ content leads to increasing chroma of chrysoprase.

\begin{tabular}{|l|l|l|l|l|l|l|}
\hline Categories & $\overline{\mathrm{w}}($ Moganite) $/ \%$ & $\overline{\mathrm{w}}(\mathrm{NiO}) / \%$ & $\overline{\mathrm{L}}^{*}$ & $\overline{\mathrm{C}}^{*}$ & $\overline{\mathrm{h}}^{\circ}$ & Simulated colour \\
\hline $\mathrm{w}_{1} \%(30-40)$ & 36.09 & 0.83 & 53.10 & 26.95 & 167.60 & \\
\hline $\mathrm{w}_{2} \%(40-50)$ & 43.97 & 1.14 & 53.55 & 35.04 & 164.80 & \\
\hline $\mathrm{w}_{3} \%(50-60)$ & 54.28 & 1.90 & 47.09 & 38.75 & 161.48 & \\
\hline $\mathrm{w}_{4} \%(60-70)$ & 64.95 & 2.08 & 47.24 & 42.51 & 159.58 & \\
\hline
\end{tabular}




\begin{tabular}{|l|l|l|l|l|l|l|}
\hline $\mathrm{w}_{5} \%(70-80)$ & 72.19 & 2.87 & 49.83 & 46.67 & 163.46 & \\
\hline
\end{tabular}

Table 7. The average Moganite and average colour parameters of 5 categories.

\section{Conclusion}

Under a 6504-K fluorescent lamp, the colour of chrysoprase was measured and divided into the grades of fancy, fancy intense and fancy deep. There was moderate negative correlation between the lightness $L^{*}$ and the $\mathrm{Cr}$ content, high positive correlation between the chroma $C^{*}$ and the $\mathrm{Ni}$ content, and moderate negative correlation between the hue angle $h^{\circ}$ and the sum of the Fe and $\mathrm{Cr}$ contents. The wavelength corresponding to the lowest absorption value in the blue-green region of the spectrum shifted to the short-wave direction with increasing sum of the $\mathrm{Cr}$ and $\mathrm{Fe}$ contents. The colour change exhibited decreasing hue angle, and the hue tended to yellowish green. The absorption peak at $660 \mathrm{~nm}$ was caused by the $\mathrm{d}$-d transition of $\mathrm{Ni}^{2+}$, and increasing $\mathrm{Ni}$ content led to increasing area of the absorption peak at $660 \mathrm{~nm}$ in the UV-Vis spectrum, which was manifested as increasing chroma of chrysoprase.

With decreasing crystallinity of chrysoprase, its $\mathrm{Ni}$ content and chroma increase. The colour of chrysoprase results from nanometre-size inclusions of $\mathrm{Ni}$-bearing pimelite, and chrysoprase with low crystallinity has more microstructure defects that can accommodate more $\mathrm{Ni}$-bearing pimelite. The higher the Ni content, the stronger the chrysoprase colour, which shows the increase of chroma. 


\section{Methods}

Transmission electron microscopy. Micrometer-size fragments of chrysoprase were ground in an agate mortar. The resulting powders were placed on a holey carbon thin-film supported by a Cu grid. A JEOL JEM F200 type transmission electron microscope (TEM) equipped with Oxford 65T energy dispersive spectrometer (EDS) was used for this study. All TEM observations were carried out at $200 \mathrm{kV}$ operating voltage.

Colourimetric analysis. Chrysoprase colour was quantified by MDIS-f8 multifunction dual integrating sphere spectrometer, which collects reflective signals on the chrysoprase surface. The test conditions were described as follows: the range of wavelength, $380-760 \mathrm{~nm}$; Spectral resolution: $1 \mathrm{~nm}$; $\mathrm{CIE}$ standard illumination, $\mathrm{D} 65$; Thermal stable temperature, $30^{\circ} \mathrm{C}$; voltage of $220 \mathrm{v}$ and frequency of $50-60 \mathrm{~Hz}$.

EDXRF. Micro-area chemical components were measured by an EDX-7000 Energy Dispersive Xray fluorescence spectrometer with the test conditions as follows: atmosphere, oxide; voltage of $50 \mathrm{kV} ; 108 \mu \mathrm{A} ; 30 \% \mathrm{DT}$; collimator, $5 \mathrm{~mm}$.

UV-Vis spectra. Absorption spectra and transmission spectra in the ultraviolet to visible (UV-Vis) range were recorded with a UV-3600 UV-VIS spectrophotometer. The test conditions were described as follows: the range of wavelength, 200-1000nm; scanning speed, high; sampling interval, $1.0 \mathrm{~s}$; scanning mode, single.

Raman spectra. The Raman spectra were measured with Horiba LabRAM HR Evolution Raman spectrometer equipped with a Peltier-cooled charged-coupled device(CCD) detector, edge filters, and a Nd-YAG laser. The test conditions were described as follows: the range of wavelength, $200 \mathrm{~cm}^{-1}-2000 \mathrm{~cm}^{-1}$; acq.time, $3.0 \mathrm{~s}$; accumulations, 1; autofocus, off; autoexposure, off; spike flitter, multiple accum; Delay time, $0.0 \mathrm{~s}$; binning, 1; readout mode, signal; denoise, lite; ICS correction, On; dark correction, off; inst. Process, off; objective, x50_VIS_LWD; grating 1800(500nm); ND filter, 100\%; laser, 532nm_Edge.

\section{Data availability}

The dataset for this study is available from the corresponding author upon reasonable request.

\section{References}

1. Eggleton, R. A., Fitz Gerald, J. \& Foster, L. Chrysoprase from Gumigil, Queensland. Australian Journal of Earth Sciences 58, 767-776 (2011).

2. Shigley, J. E., Laurs, B. M. \& Renfro, N. D. Chrysoprase and prase opal from Haneti, Central Tanzania. Gems \& Gemology 45, 271-279 (2009).

3. Graetsch, H. A. Microstructure and origin of colour of chrysoprase from Haneti (Tanzania). Neues Jahrbuch für Mineralogie-Abhandlungen, 111-117 (2011).

4. Čermáková, Z., Hradil, D., Bezdička, P. \& Hradilová, J. New data on "kerolite-pimelite" series and the colouring agent of Szklary chrysoprase, Poland. Physics and Chemistry of Minerals 44, 193-202 (2017). 
5. Sachanbiński, M., Janeczek, J., Platonov, A. \& Rietmeijer, F. J. The origin of colour of chrysoprase from Szklary (Poland) and Sarykul Boldy (Kazakhstan). Neues Jahrbuch für Mineralogie-Abhandlungen: Journal of Mineralogy and Geochemistry 177, 61-76 (2001).

6. Gawel, A., Olkiewicz, S. \& Zabinski, W. XRD and IR spectroscopic investigations of some chrysoprases. Mineralogia Polonica 28, 43-51 (1997).

7. Rossman, G. R. The colored varieties of the silica minerals. Silica Reviews in Mineralogy 29, $433-467$ (1994).

8. Nagase, T., Akizuki, M., Onoda, M. \& Sato, M. Chrysoprase from Warrawanda, Western Australia. Neues Jahrbuch fur Mineralogie, Monatshefte, 289-300 (1997).

9. Heflik, W., Kwiecinska, B. \& Natkaniec-Nowak, L. Colour of chrysoprase in light of mineralogical studies. The Australian Gemmologist 17, 43-46 (1989).

10. Barsanov, G. \& Yakovleva, M. Mineralogical investigations of some precious and semiprecious varieties of cryptocrystalline silica. New Mineral Data. USSR Acad. Sci 29, 1981 (1981).

11. Krzemnicki, M. S., Hanni, H. \& Reusser, E. Colour change garnets from Madagascar: Comparison of colorimetric with chemical data. Journal of Gemmology 27, 395-408, (2001).

12. Schmetzer, K., Bernhardt, H.-J., Bosshart, G. \& Hainschwang, T. Colour-change garnets from Madagascar: variation of chemical, spectroscopic and colorimetric properties. Journal of Gemmology 31, 235-282 (2009).

13. Sun, Z., Palke, A. C. \& Renfro, N. Vanadium-and chromium-bearing pink pyrope garnet: characterization and quantitative colorimetric analysis. Gems \& Gemology 51, 348-369 (2015).

14. Sun, Z. et al. Eds. GN: discovery of color-change chrome grossular garnets from Ethiopia. Gems Gemology 54, 233-236 (2018).

15. Liu, Y., Shigley, J. \& Halvorsen, A. Colour hue change of a gem tourmaline from the Umba Valley, Tanzania. Journal of Gemology-London- 26, 386-396 (1999).

16. Guo, Y. Quality evaluation of tourmaline red based on uniform color space. Cluster Computing 20, 3393-3408 (2017).

17. Han, J. Y., Guo, Y. \& Liu, S. Environmental issues on color quality evaluation of blue sapphire based on gemdialoguetm color comparison charts. Ekoloji Dergisi, 1365-1376 (2018).

18. Liu, Y., Shigley, J., Fritsch, E. \& Hemphill, S. The "alexandrite effect" in gemstones. Color Research \& Application 19, 186-191 (1994). 
19. Tang, J., Guo, Y. \& Xu, C. Metameric effects on peridot by changing background color. J Opt Soc Am A Opt Image Sci Vis 36, 2030-2039, (2019).

20. Tang, J., Guo, Y. \& Xu, C. Light pollution effects of illuminance on yellowish green forsterite color under CIE standard light source D65. Ekoloji 27, 1181-1190 (2018).

21. Sun, Z., Renfro, N. \& Palke, A. C. Tri-color-change holmium-doped synthetic CZ. Gems \& Gemology 53, 259-260 (2017).

22. Liu, Y., Shi, G. H. \& Wang, S. Color phenomena of blue amber. Gems \& Gemology 50, 134-140 (2014).

23. Guo, Y., Wang, H. \& Du, H. The foundation of a color-chip evaluation system of jadeite-jade green with color difference control of medical device. Multimedia Tools and Applications 75, 14491-14502 (2016).

24. Guo, Y., Wang, H., Li, X. \& Dong, S. Metamerism appreciation of jadeite-jade green under the standard light sources D65, A and CWF. Acta Geologica Sinica-English Edition 90, 2097-2103 (2016).

25. Guo, Y. Quality grading system of Jadeite-Jade green based on three colorimetric parameters under CIE standard light sources D65, CWF and A. Bulgarian Chemical Communications 49, 961-968 (2017).

26. Guo, Y., Zong, X. \& Qi, M. Feasibility study on quality evaluation of Jadeite-jade color green based on GemDialogue color chip. Multimedia Tools and Applications 78, 841-856 (2019).

27. Guo, Y., Zong, X., Qi, M., Zhang, Y. \& Wang, H. Feasibility study on color evaluation of jadeite based on GemDialogue color chip images. EURASIP Journal on Image and Video Processing 2018, 1-9 (2018).

28. Guo, Y., Zhang, X., Li, X. \& Zhang, Y. Quantitative characterization appreciation of golden citrine golden by the irradiation of [Fe04] ${ }^{4-}$. Arabian journal of chemistry 11, 918-923 (2018).

29. Cheng, R. P. \& Guo, Y. Study on the effect of heat treatment on amethyst color and the cause of coloration. Scientific reports 10, 1-12 (2020).

30. McLaren, K. XIII-The development of the CIE $1976\left(\mathrm{~L}^{*} \mathrm{a}^{*} \mathrm{~b}^{*}\right)$ uniform colour space and colour-difference formula. Journal of the Society of Dyers and Colourists 92, 338-341 (1976). 
31. Brindley, G., Bish, D. \& Wan, H.-M. Compositions, structures, and properties of nickelcontaining minerals in the kerolite-pimelite series. American Mineralogist 64, 615-625 (1979).

32. Gérard, P. \& Herbillon, A. Infrared studies of Ni-bearing clay minerals of the kerolite-pimelite series. Clays and Clay Minerals 31, 143-151 (1983).

33. Cathelineau, M., Caumon, M. C., Massei, F., Brie, D. \& Harlaux, M. Raman spectra of Ni-Mg kerolite: effect of $\mathrm{Ni}-\mathrm{Mg}$ substitution on $\mathrm{O}-\mathrm{H}$ stretching vibrations. Journal of Raman Spectroscopy 46, 933-940 (2015).

34. Wells, M. A., Ramanaidou, E. R., Verrall, M. \& Tessarolo, C. Mineralogy and crystal chemistry of "garnierites" in the Goro lateritic nickel deposit, New Caledonia. European Journal of Mineralogy 21, 467-483 (2009).

35. Villanova-de-Benavent, C. et al. Ni-phyllosilicates (garnierites) from the Falcondo Ni-laterite deposit (Dominican Republic): Mineralogy, nanotextures, and formation mechanisms by HRTEM and AEM. American Mineralogist 101, 1460-1473 (2016).

36. King, J., Moses, T., Shigley, J. \& Liu, Y. Color grading of colored diamonds in the GIA Gem Trade Laboratory. Gems \& Gemology 30, 220-242 (1994).

37. Reddy, B. J. \& Frost, R. L. Electronic and vibrational spectra of gaspeite. Neues Jahrbuch für Mineralogie - Monatshefte 2004, (2004).

38. Faye, G. Optical absorption spectrum of $\mathrm{Ni}^{2+}$ in garnierite; a discussion. The Canadian Mineralogist 12, 389-393 (1974).

39. Rao, J. L. \& Purandar, K. Optical absorption spectrum of $\mathrm{Ni}^{2+}$ in zinc cesium sulphate hexahydrate. Spectrochimica Acta Part A: Molecular Spectroscopy 37, 787-792 (1981).

40. Zhou, D. Y., Chen, H., Lu, T. J., Ke, J. \& He, M. Y. Study on the relationship between the relative content of moganite and the crystallinity of quartzite jade by raman scattering spectroscopy, infrared absorption spectroscopy and x- ray diffraction techniques. Rock and Mineral Analysis 34, 652-658 (2015).

41. Kingma, K. J. \& Hemley, R. J. Raman spectroscopic study of microcrystalline silica. American Mineralogist 79, 269-273 (1994).

42. Zhang, M. \& Moxon, T. Infrared absorption spectroscopy of SiO2-moganite. Am Mineral 99, 671-680 (2014). 
43. Graetsch, H. A. \& Miehe, G. Crystal structure of moganite: a new structure type for silica. European Journal of Mineralogy 4, 693-706 (1992).

44. Götze, J., Nasdala, L., Kleeberg, R. \& Wenzel, M. Occurrence and distribution of "moganite" in agate/chalcedony: a combined micro-Raman, Rietveld, and cathodoluminescence study. Contributions to Mineralogy and Petrology 133, 96-105 (1998).

\section{Acknowledgements}

The experiments in this research were conducted in the lab of the Gemological Institute, China University of Geosciences, Beijing and the Institute of Tibetan Plateau Research, Chinese Academy of Sciences. We would like to thank Shuai nan and Weixin Li for kind help in our experiments.

\section{Author contributions}

Yuansheng Jiang and Ying Guo chose raw materials as samples and conducted experiments and data analysis together, Yuansheng Jiang wrote the main manuscript texts and prepared figures, and Ying Guo revised and corrected the manuscript texts.

\section{Competing interests}

The authors declare no competing interests. 


\section{Figures}

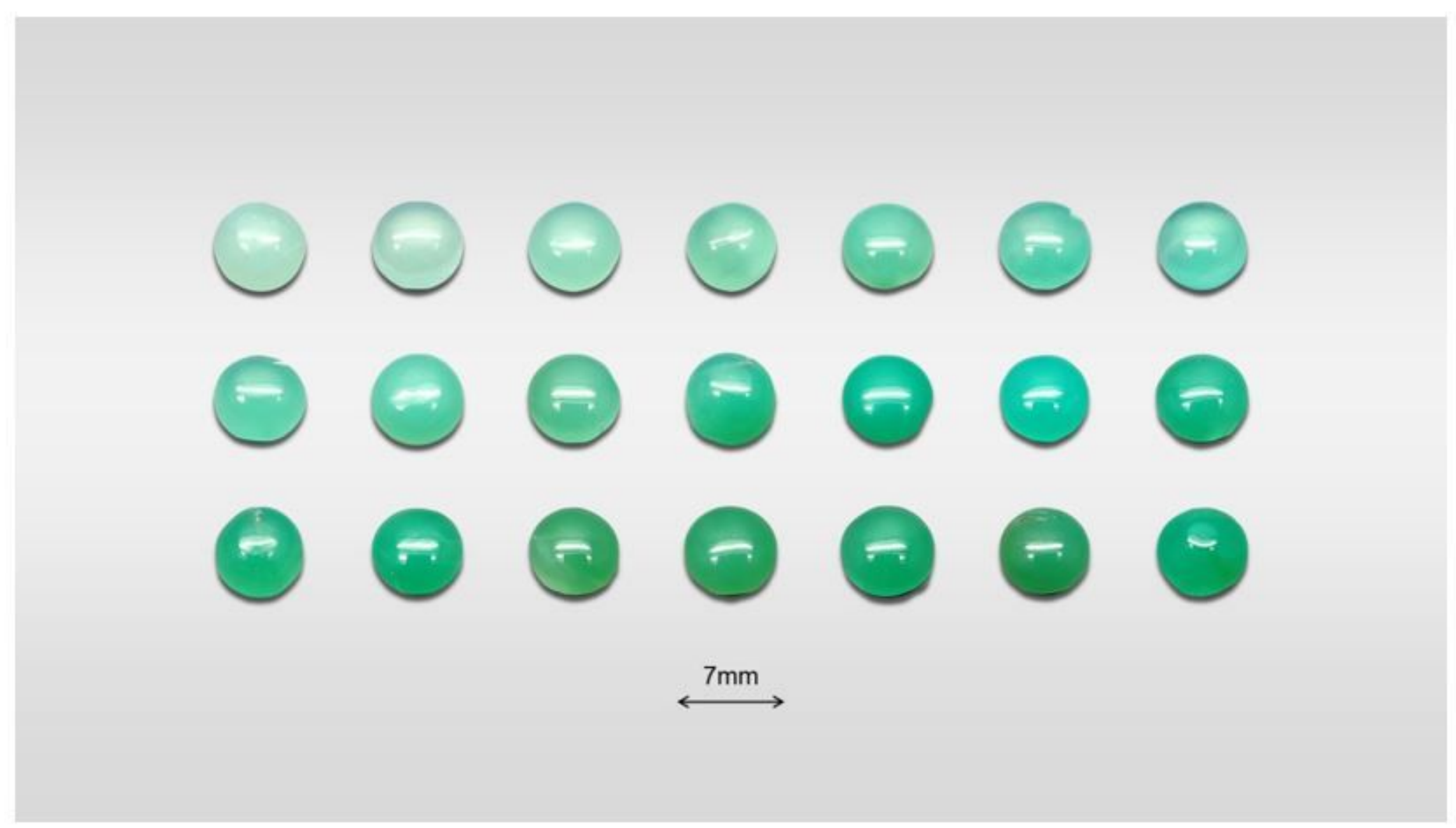

\section{Figure 1}

Photograph of some of the samples used in the present study. The round flat samples used for colourparameter testing had an average mass of $3.96 \mathrm{~g}$, and the sample in the lower-right corner of the picture was subjected to transmission electron microscopy (TEM). 

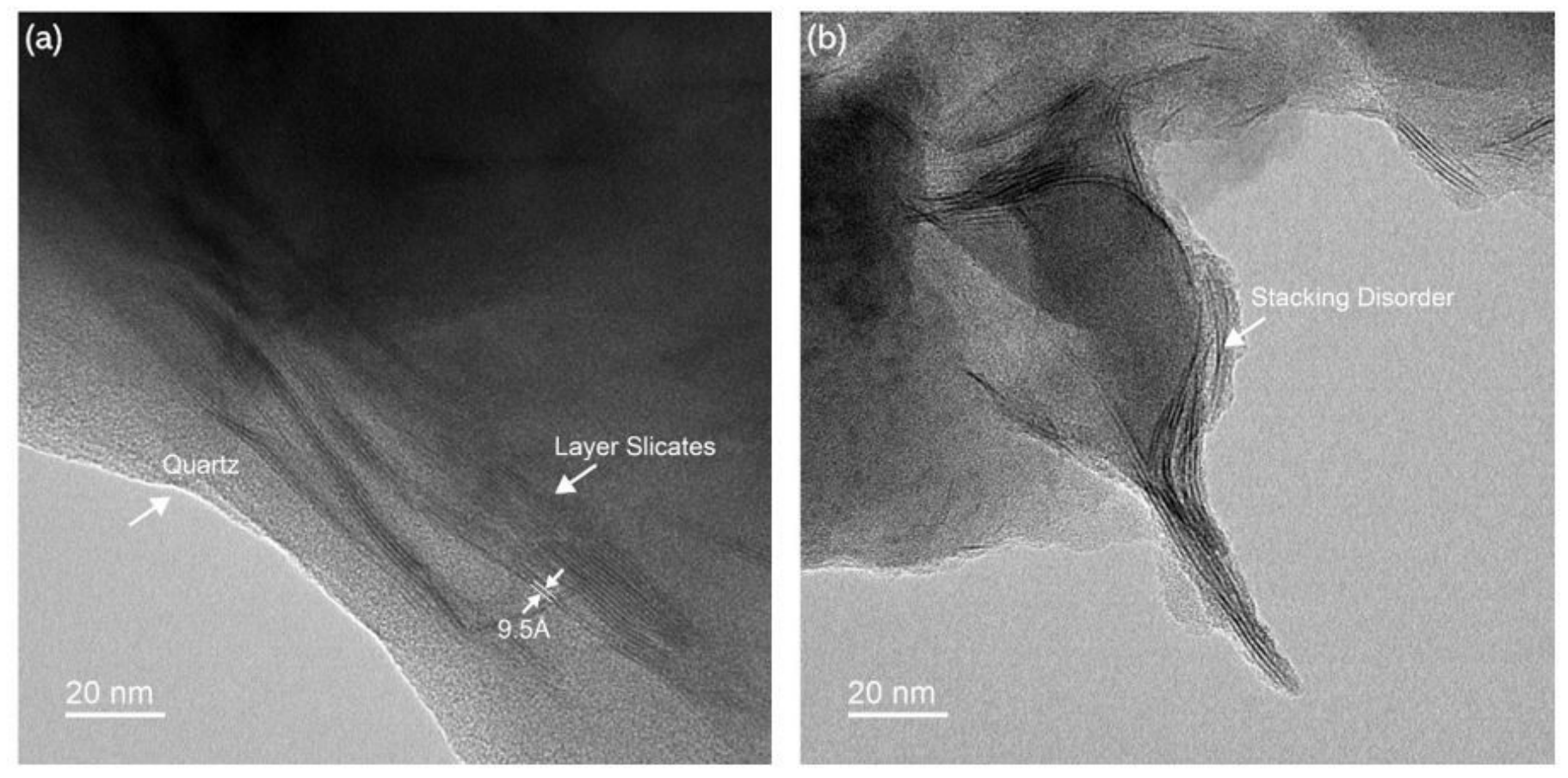

Figure 2

Results of TEM observations. (a) In chrysoprase, nanometre-size layer silicates with between five and 20 layers with similar interlayer distances of $\sim 9.5 \AA$ are found frequently in the quartz crystals and at their boundaries. (b) A TEM image of the layer silicates in chrysoprase, where the lattice fringes show the stacking disorder. 

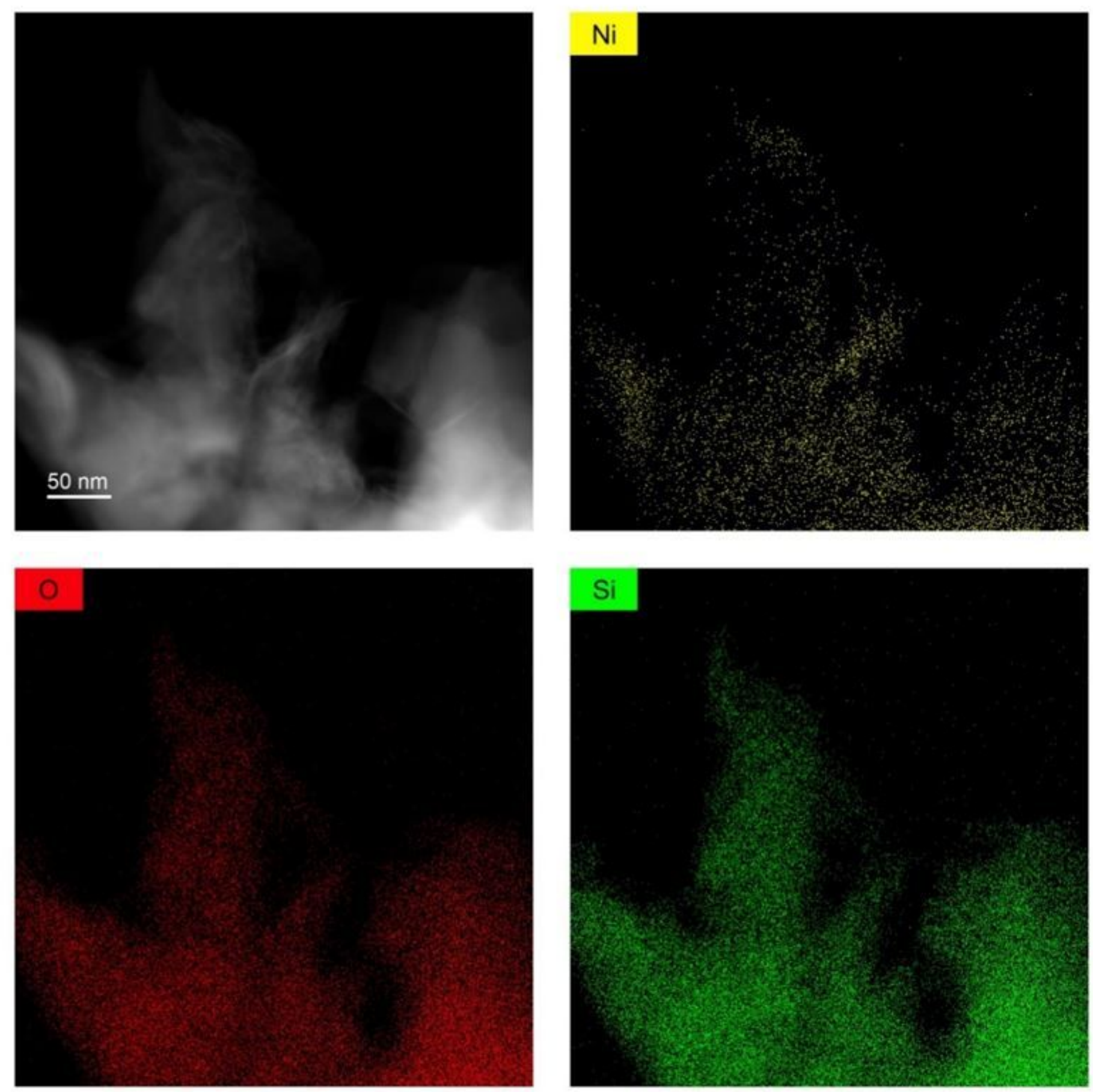

\section{Figure 3}

Elemental maps produced by energy-dispersive spectrometer. The yellow, red and green colour sites correspond to the distributions of $\mathrm{Ni}, \mathrm{O}$ and $\mathrm{Si}$, respectively. No $\mathrm{Mg}$ was detected. 


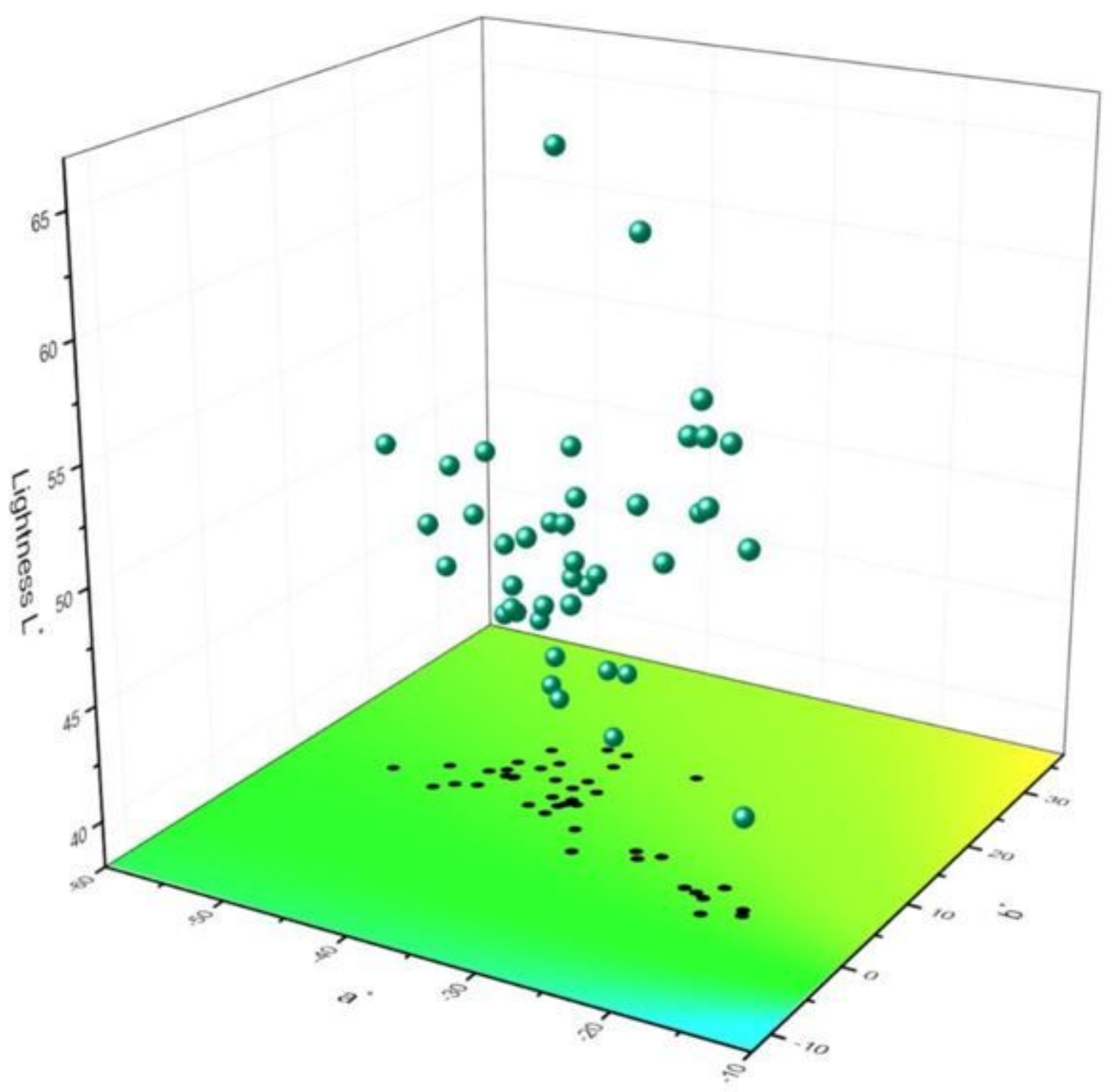

Figure 4

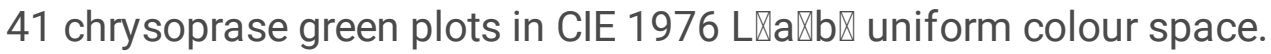


(a)
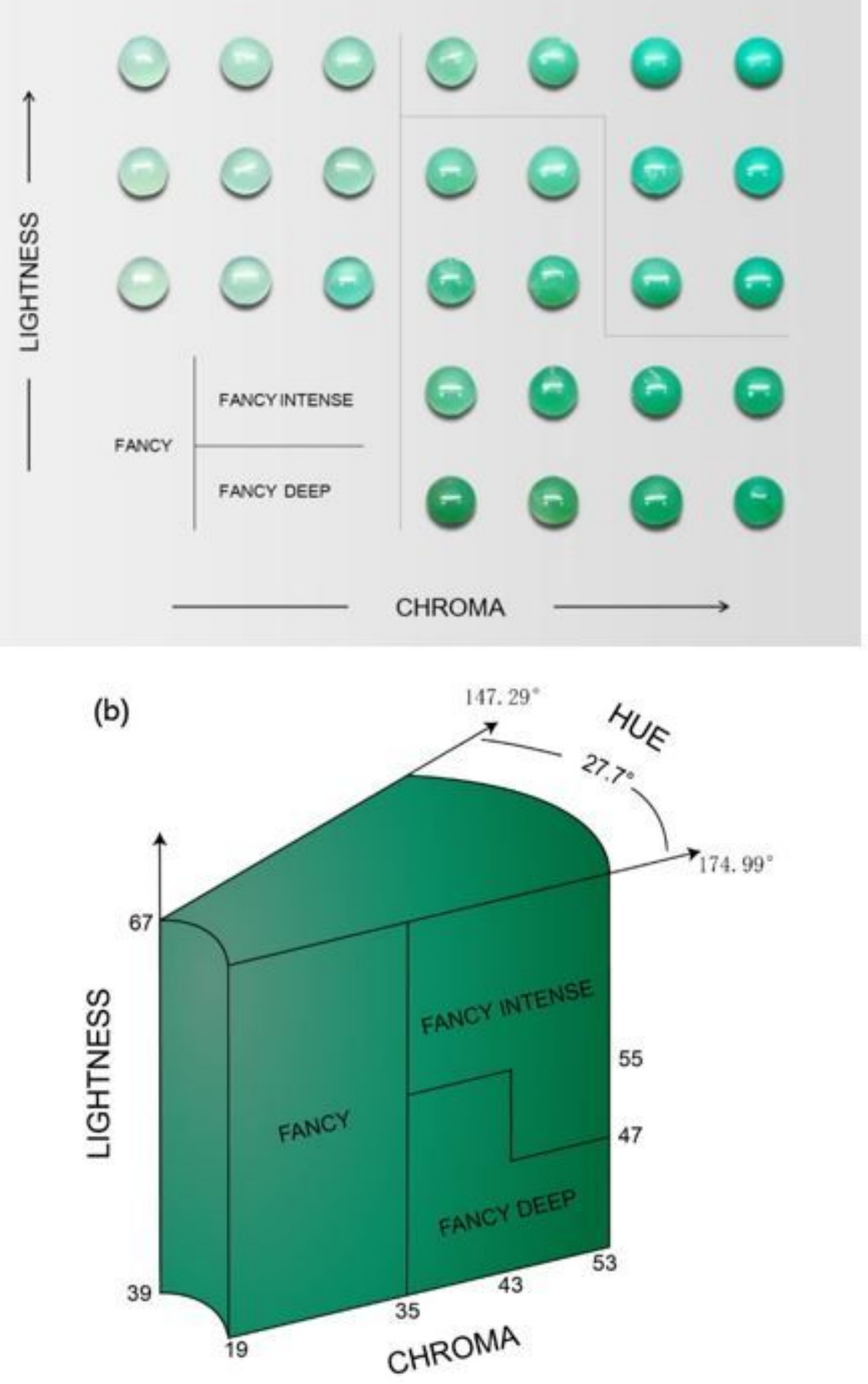

Figure 5

Colour grading of chrysoprase. (a) Chrysoprase colour is graded into the levels of fancy, fancy intense and fancy deep. (b) Chrysoprase colour grading system. 

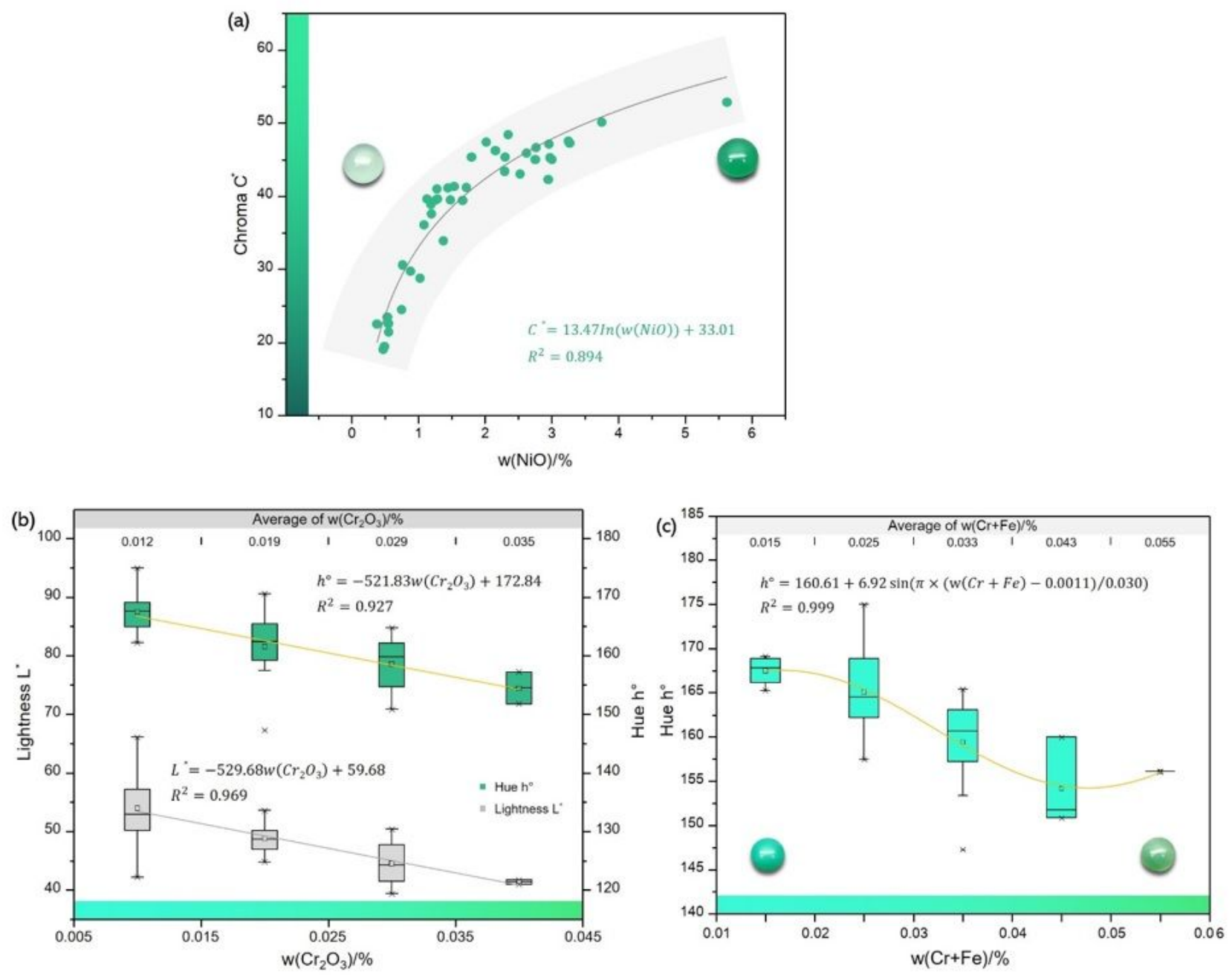

\section{Figure 6}

Relationship between colour parameters and transition-metal elements. (a) There is a highly positive correlation between $\mathrm{Ni}$ content and chroma. (b) With increasing $\mathrm{Cr}$ content, the lightness and hue angle exhibit downward trends. (c) Both $\mathrm{Cr}$ and Fe affect the hue angle; the higher the content of $\mathrm{Cr}$ and $\mathrm{Fe}$, the smaller the hue angle. 

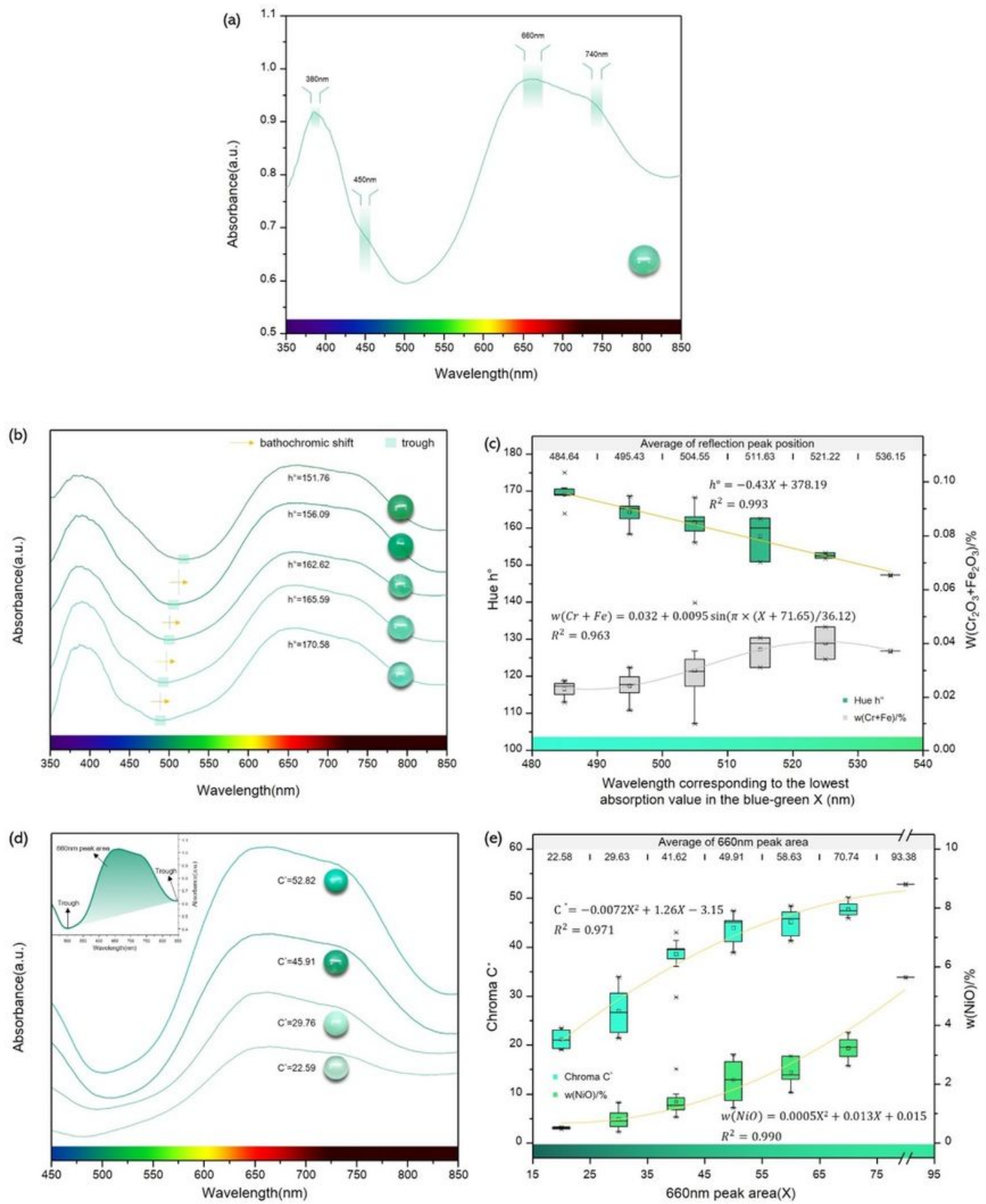

\section{Figure 7}

UV-Vis spectra for chrysoprase samples. (a) The UV-Vis spectra of chrysoprase are characterized by $\mathrm{Ni} 2+$ absorption features. (b) The transmission window between the two main bands of chrysoprase centred at 380 and $660 \mathrm{~nm}$ is responsible for the hue of the samples. (c) Relationship between the wavelength corresponding to the lowest absorption value in the blue-green region and hue and $\mathrm{w}(\mathrm{Cr} 2 \mathrm{O3}+\mathrm{Fe} 2 \mathrm{O3})$. (d) The larger the area of the 660-nm absorption peak, the greater the chroma of 
chrysoprase. (e) Relationship between the 660-nm peak area and chroma and w(NiO)\%. The chroma and $\mathrm{Ni}$ content of chrysoprase increase with increase of the 660-nm peak area.
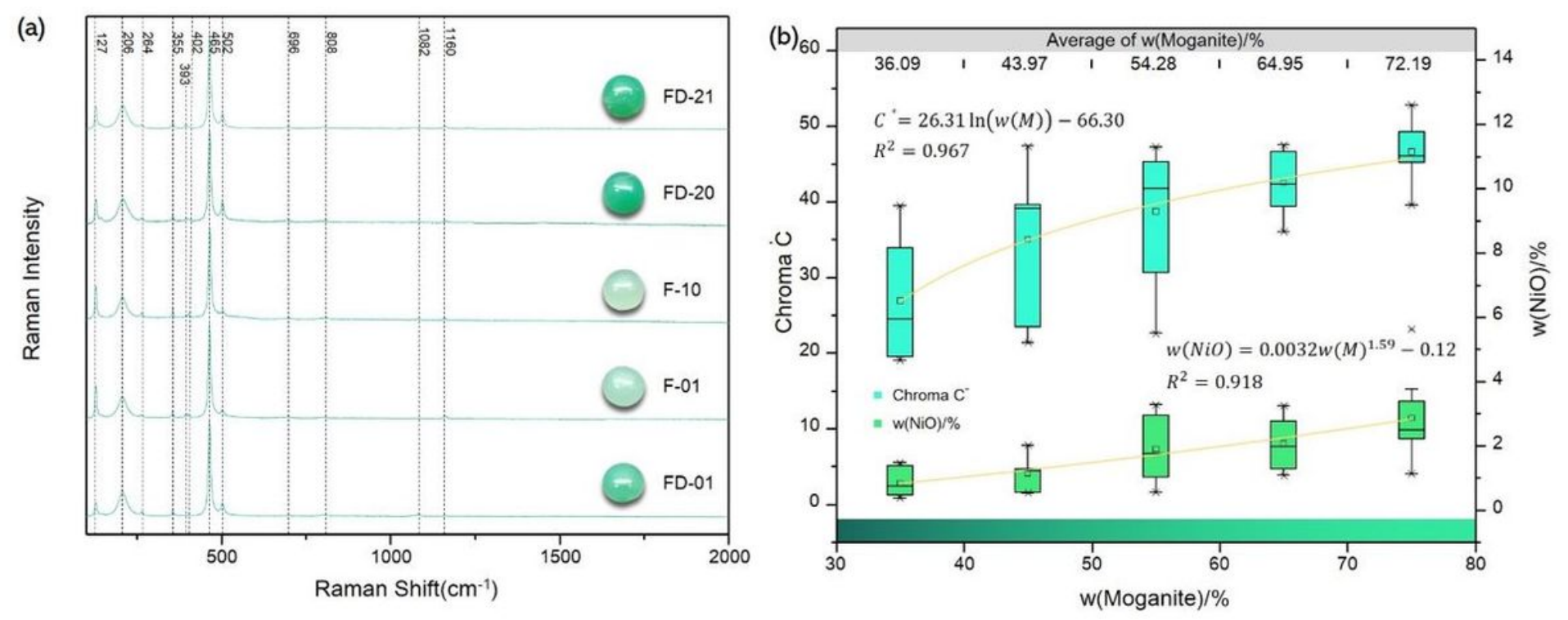

Figure 8

(a) Raman spectra of chrysoprase. All samples show standard Raman peaks of a-quartz and the characteristic peak of moganite of $502 \mathrm{~cm}-1$. (b) Relationship between w(Moganite) and chroma and $\mathrm{w}(\mathrm{NiO})$. The chroma and $\mathrm{Ni}$ content of chrysoprase both increase with increasing moganite content.

\section{Supplementary Files}

This is a list of supplementary files associated with this preprint. Click to download.

- supplementaryinformation.docx 